\title{
RELATÓRIO SOBRE A OCUPAÇÃO DOS MORROS DO MALUF E SOROCOTUBA (GUARUJÁ, SP)
}

CEPA - Comissão de Estudos dos Problemas Ambientais da Universidade de São Paulo.

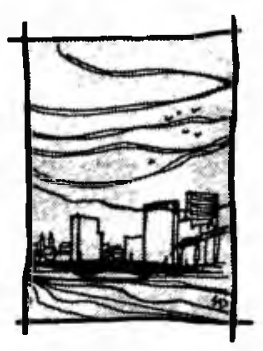

O setor do litoral brasileiro, entre a Baixada Santista, SP e a Baía da Ilha Grande, RJ, é um dos que mais se destaca pela aproximação da Serra do Mar à faixa litorânea, por meio de esporões divisores de água, que descem em pata-mares da serra e que separam as planícies costeiras onde se situam os morros e maciços costeiros. Tais aspectos dão ao setor qualidades paisagísticas excepcionais, com seus recortes litorâneos em enseadas e baías, suas matas e manguezais.

Esta estrutura única, próxima a grandes centros urbanos (São Paulo, Rio de Janeiro e cidades do Vale do Paraíba) é naturalmente o grande centro de lazer turístico para os seus habitantes, bem como os de cidades situadas no interior. Tal estrutura permite ao ser humano uma convivência com os elementos da natureza, alguns dos quais praticamente extintos no resto do estado de São Paulo. Como exemplos desses elementos, podemos apontar as reservas florestais da Serra do Mar, tombadas há pouco pelo CONDEPHAAT e as águas fluviais e marinhas para banhos, esportes náuticos e subaquáticos.

Apesar da ocupação urbana relativamente grande e algumas dificuldades de acesso e de espaço físico, a estrutura da paisagem pré-existente encontra-se, em grande parte. ainda intacta. Ao lado de praias densamente povoadas, há morros cobertos de matas e outras áreas desocupadas. Essa convivência do urbano e do não urbano coloca a área numa posição turística excepcional, onde se pode usufruir desse "cenário" de configuração tão variada. A inserção das praias nesse quadro natural e atraente dá oportunidade a que a valorização imobiliária se intensifique e se multiplique o movimento turístico.

A partir dessa intensificação e especulação imobiliária-turística. ocorreram muitos fenômenos que vieram destruir a organização ambiental, dentre eles a ocupação desordenada, a poluição, as contaminações, o desmatamento a destruição dos materiais superficiais nas vertentes e a desorganização da drenagem pluvial. 


\section{CARACTERIZAÇĀO GEOMORFOLÓGICA}

O LITORAL é a zona de contato e de inter-relações entre a terra e mar.

É a faixa terrestre diretamente atingida pelas águas marinhas, incluindo respingos, correntes de vagas e de marés. Abrange essencialmente as praias. as frentes dos costões rochosos dos morros e os manguezais (Ab'Saber, 1962). Essa faixa pela legislação em vigor pertence à Marinha.

A ÁREA COSTEIRA é a abrangida pelo litoral e os terrenos à retaguarda, sejam eles de origem marinha, sejam de origem mista fluvio-marinho-lagunar com solos arenosos orgânicos, vasoso-pantanosos e de origem continental. Tais terrenos compõem as planícies costeiras ou baixadas formadas em função das variações do nível do mar através de transgressões e regressões no decorrer do quaternário, soldando ao continente antigas ilhas que hoje constituem os morros e maciços costeiros. No estado de São Paulo esta área pertence aquela que Almeida (1964) chama de Província Costeira.

Abaixo do nível do mar, o infralitoral, a plataforma continental e as ilhas continentais são a continuação das mesmas formações rochosas dos morros e maciços costeiros.

MORROS e MACIÇOS COSTEIROS Na costa sudeste-sul brasileira, o recuo das escarpas da Serra do Mar para oeste, desde sua formação, deixou a leste, ilhas de núcleos rochosos mais resistentes (Almeida. 1976).

Atualmente estão soldadas ao continente pelas formações sedimentares dos cordões arenosos em feixes de antigas restingas e tômbolos, por efeito das últimas transgressões e regressões marinhas. Fazem parte das planícies costeiras ou baixadas e são denominados morfologicamente de morros e maciços costeiros. Os morros são isolados (exemplo típico é o Morro do Maluf), enquanto os maciços constituem corpos rochosos maiores, numa continuidade de morros com topos mais elevados abaulados ou em cristais (exemplo típico é o maciço na parte central da Ilha de Santo Amaro. (figura 1)

Assim, os morros e maciços costeiros. bem como as escarpas da Serra do Mar, possuem grande valor ambiental, tanto pela beleza da morfologia de suas vertentes florestadas, como pela sua importância ecológica como também pela boa qualidade do ar, devendo, portanto, ser encarados como patrimônio público e objetos de conservação. 


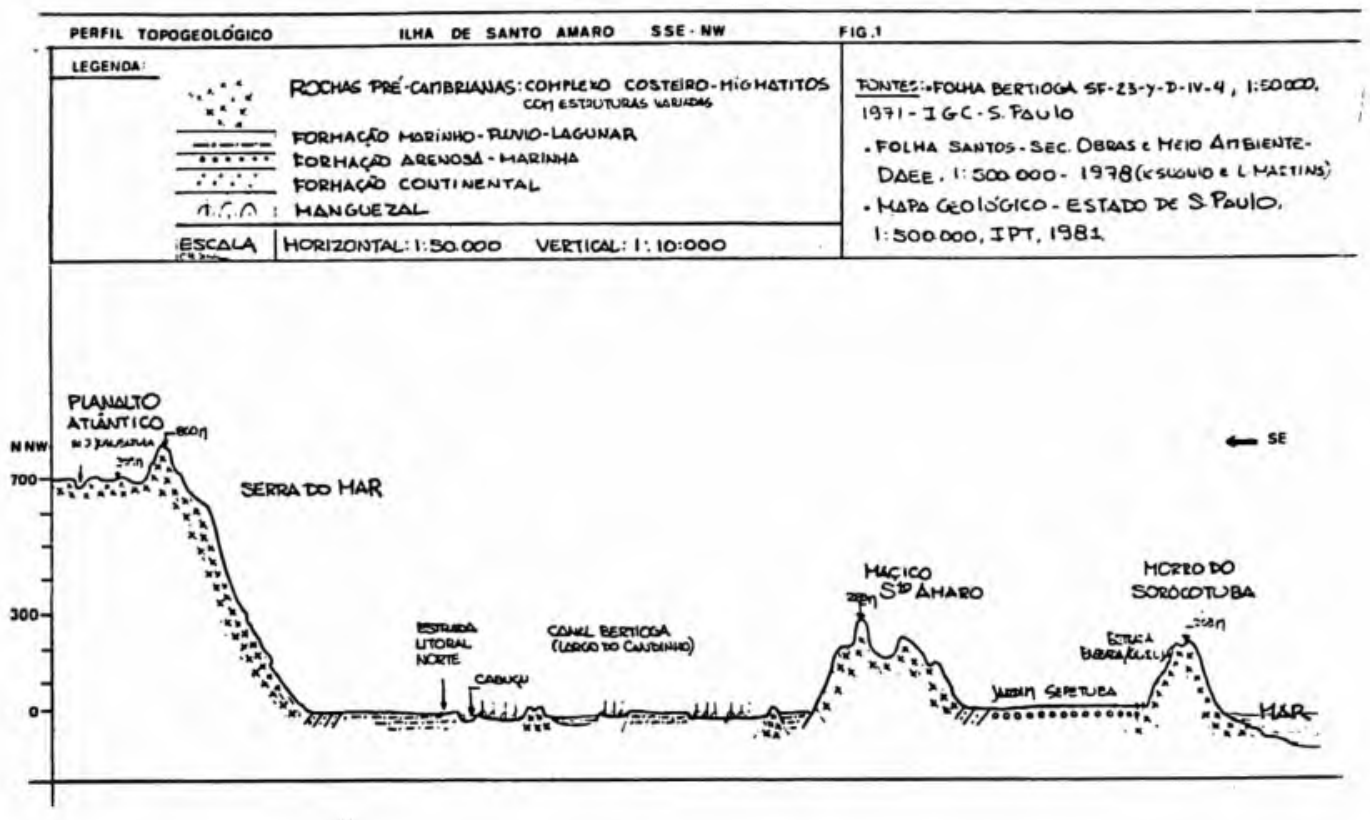

Com os efeitos do clima atual sobre um sistema morfogenético de áreas quentes e úmidas, suas rochas se alteram por intemperismo e pedogênese. Por isto, suas encostas apresentam freqüentemente espessos materiais intemperizados superficiais, inconsistentes íngremes e florestadas dos morros, maciços e escarpas da Serra do Mar, estão sofrendo intensas ações antropogênicas a partir do desmatamento, seus desmontes e destruição para as atividades imobiliárias, mesmo em lugares mais vulneráveis tais como:

a) bacias de captação de águas pluviais de cabeceiras em anfiteatros, com conseqüente ressecamento dos lençóis freáticos e nascentes;

b) vertentes íngremes sobretudo a partir de $22^{\circ}$ de declividade (Cruz, 1975), e propensas a escorregamentos desses materiais;

c) áreas próximas ou sobre costōes e costeiras rochosos sujeitos aos respingos e ambates das vagas.

\section{DIAGNÓSTICO DA OCUPAÇĀO DOS MORROS DO MALUF E SOROCOTUBA}

\section{ASPECTOS GERAIS}

O município de Guarujá já possui seus morros basicamente ocupados de quatro formas distintas: 
$\left.1^{\circ}\right)$ por matas que os encobrem quase que totalmente, apresentando uma estruturação com reduzida intervenção antrópica;

$\left.2^{\circ}\right)$ por construções baixas, imersas em jardins - casas que ocupam lotes muitas vezes densamente construídos, edificados ao lado de encostas florestadas e cujo sistema viário de acesso nem sempre está assentado de acordo com padrões técnicos estabelecidos, que garantam a estabilidade total das encostas. São situações em que se pode considerar a urbanização como organizada mais "suavemente" sobre a estrutura física preexistente;

$\left.3^{\circ}\right)$ por construções horizontais e verticais, que predominam sobre a cobertura vegetal, com intervenções drásticas sobre o relevo, com a descaracterização parcial da estrutura morfológica original. Como no caso anterior, as vias de acesso se tornam agentes de destruição do relevo;

$\left.4^{\circ}\right)$ predominantemente por construções verticais que os encobrem e emparedam, ou a eles se sobrepōem, com uma total descaracterização da estrutura física anterior, com a destruição das matas e a deteriorização ambiental dos costōes vizinhos devido ao acúmulo de detritos, poluição, etc.

\section{MORRO DO MALUF}

No Morro do Maluf encontram-se exemplos do que existe de mais negativo em matéria de ocupação de morros costeiros. A intensidade de urbanização é tal, que este se encontra praticamente todo descaracterizado como ponto turístico de beleza paisagística outrora singular.

Atualmente, o referido morro apresenta todo o seu contorno (na posição de baixa vertente) ocupado com um verdadeiro paredão de edifícios de mais de uma dezena de andares. Entre o paredão de edificios e o mar, foi implantada uma rua toda construída sobre aterro, com muro de arrimo com mais de uma dezena de metros de altura. As torres construídas ao seu redor, como todas edificadas no litoral, quer em terrenos planos ou encostas, obedecem a padrões típicos de áreas planas das cidades brasileiras, generalistas e pouco tem a ver com o ambiente em que se inserem. Para isto exigem um agressivo trabalho de terraplenagem, com desmonte parcial das encostas, removendo-se o solo e subsolo. Cada torre está isolada no seu lote e procura, naturalmente, explorar a visão do mar sem que se considere o seu entorno morro e outros prédios. São construídas muito próximas umas das outras e em situações de adensamento, criando barreiras à circulação de brisa marinha necessária em áreas quentes problemas de insolação na sua vizinhança e impermeabilização do solo no lote - nem sempre desejável. 


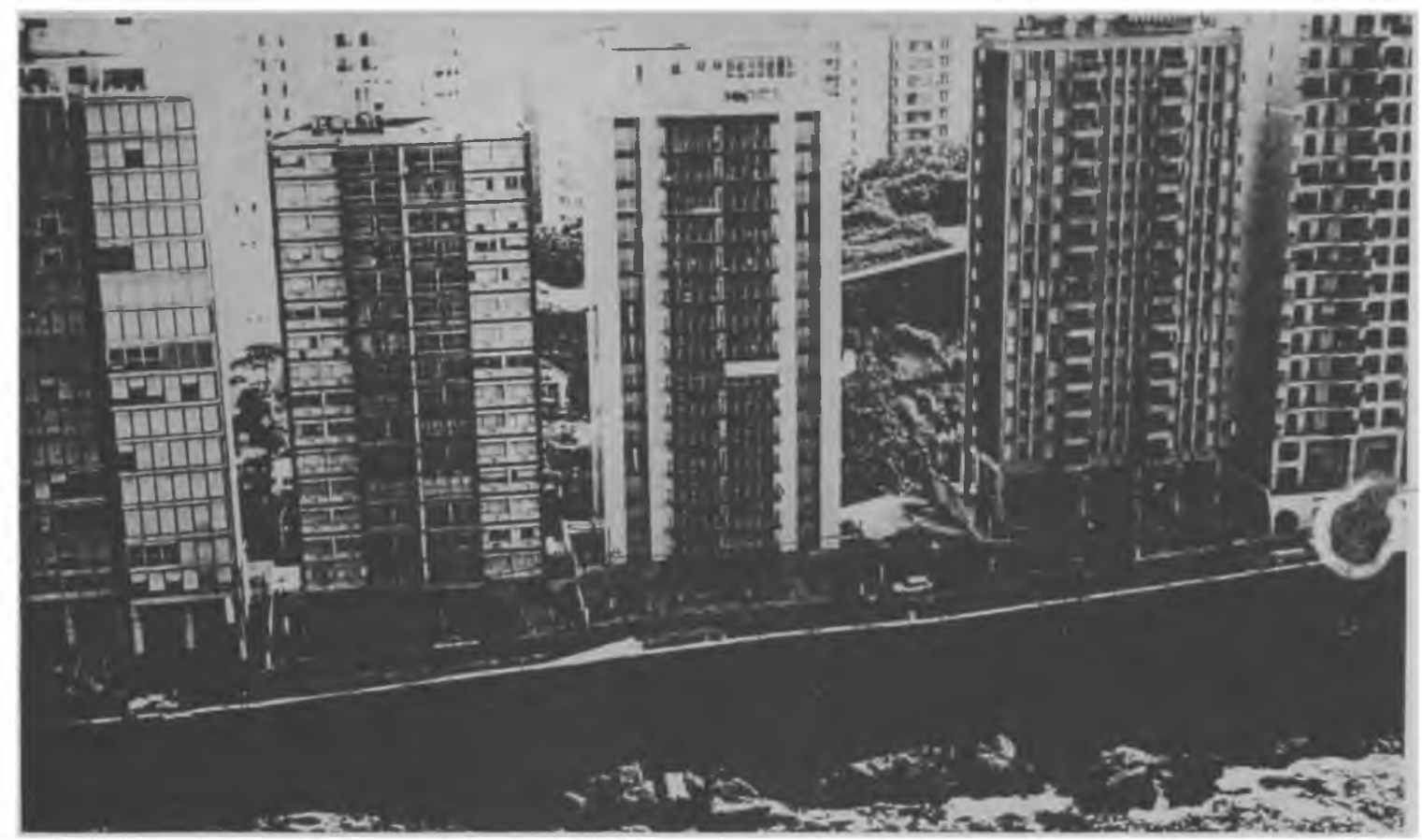

O paredão construido do Morro do Malut. constituido de torres de mais de 15 andares. muito próximas. isola o morro do seu entomo quase totalmente, que praticamente desaparece como elemento de organização da paisagem local.

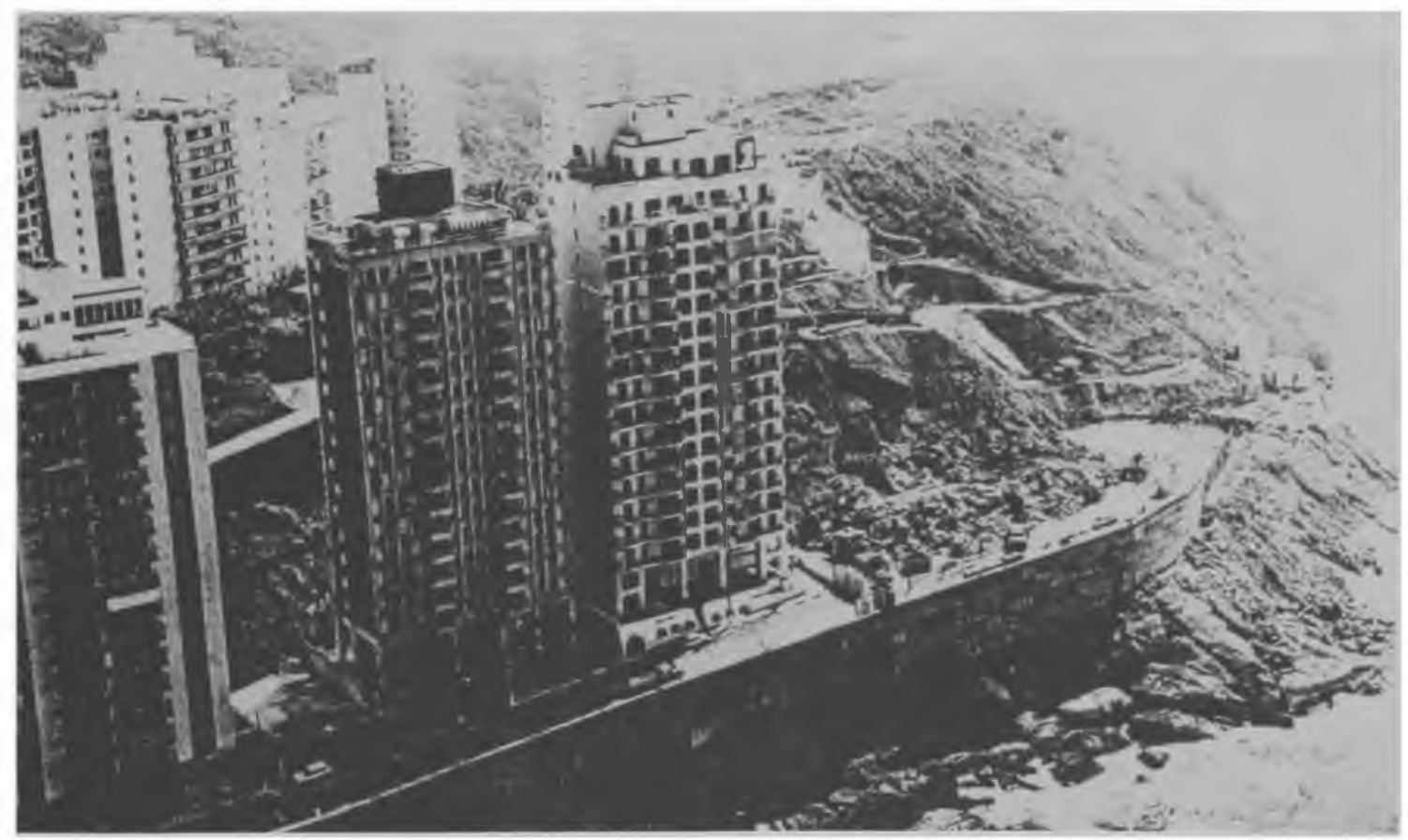

O segmento do morro ainda não ocupado por edificios de apartaumentos eslá pouco a pouco sendo ocupado. de um modo predatório por edifícios. muros e caminhos. Para sua construção foran jogados ao mar restos da obra - pedras. entulhos - . prejudicando o equilibrio ecológico do costão. 


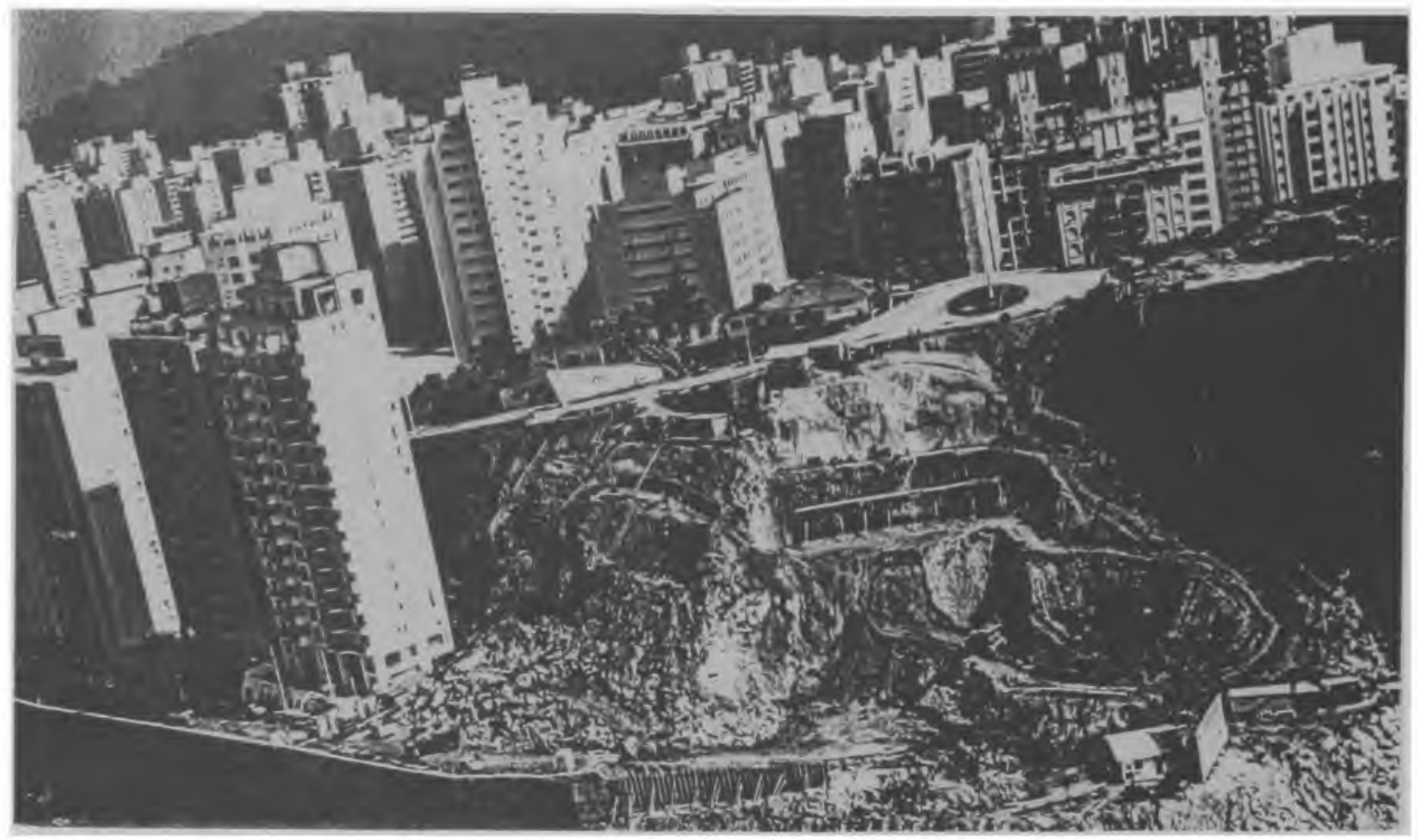

As encostas do morto ja destituidas de sua vegetação orị̌inal. recohenas apenas por gramíneas. estão sendo mais uma lez atacadas com o desmonte parcial para a construção de um novo empreendimento imobiliário. A foto mostra claramente os efeitos danosos do terrapleno sem cuidados con o entomo e os cleitos decorrentes.

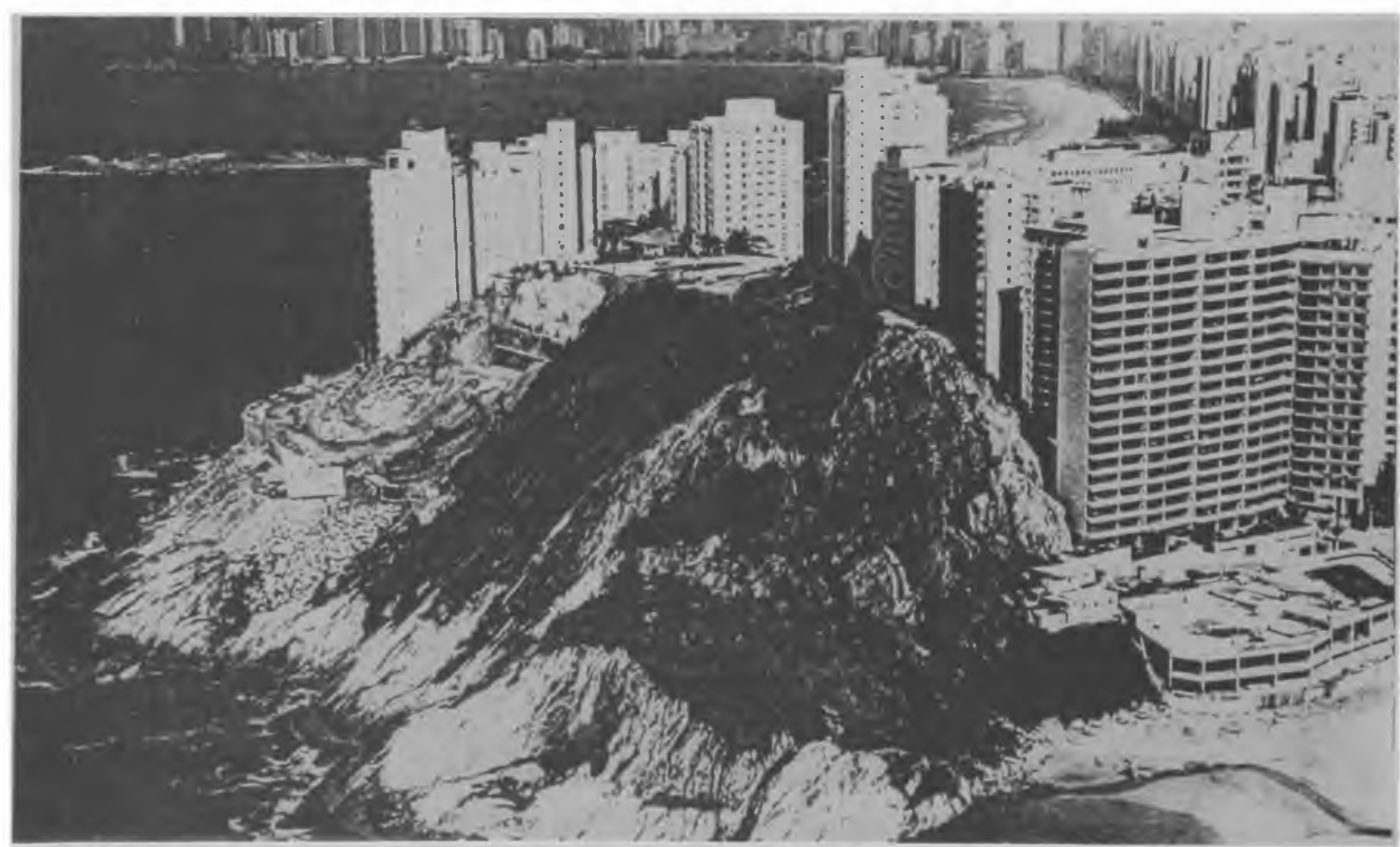

Mostra a pequena parte do morro não recobenta por edifícios ou contada por vias e é o único ponto do qual. no mirante. pode se contemplar a paisagen. Mesmo este setor já está altamente predado e guarda de típico apenas parte da morfologia do relevo. 
A um processo de verticalização. corresponde um aumento proporcional da população e em conseqüência do consumo de águas c da correspondente vazão de esgotos. tradicionalmente depositados nas águas do mar. e quando isto se processa adequadamente, a altos custos para todos. A verticalização em morros. além da destruição do próprio morro de alto valor cênico. paisagístico. $\mathrm{cm}$ muito dificulta o escoamento de águas e o abastecimento das edificaçōes. A implantação das torres. projetadas para se assentarem sobre terrenos planos exig̣e a construção de grandes terraços. Além de destruírem o relevo. implicam na destruição total da cobertura vegetal e da fauna associada existente. Como consequiência direta de erosões decorrentes são carreados ao mar volumes apreciáveis de sedimentos que comprometem a vida no ambiente marinho.

Existem. outras formas de edificações em encostas. mas esıas não são utilizadas. pois não correspondem aos padrões construtivos e formais vigentes. Cada novo bloco de apartamentos implantado destrọ́i mais do que seria necessário. Além do prédio $\mathrm{em}$ si. as garagens subterrâneas exigem para sua construção vastos movimentos de tcrras c o próprio canteiro de obras acaba colaborando na expansão da destruição do ecossistema do entorno.

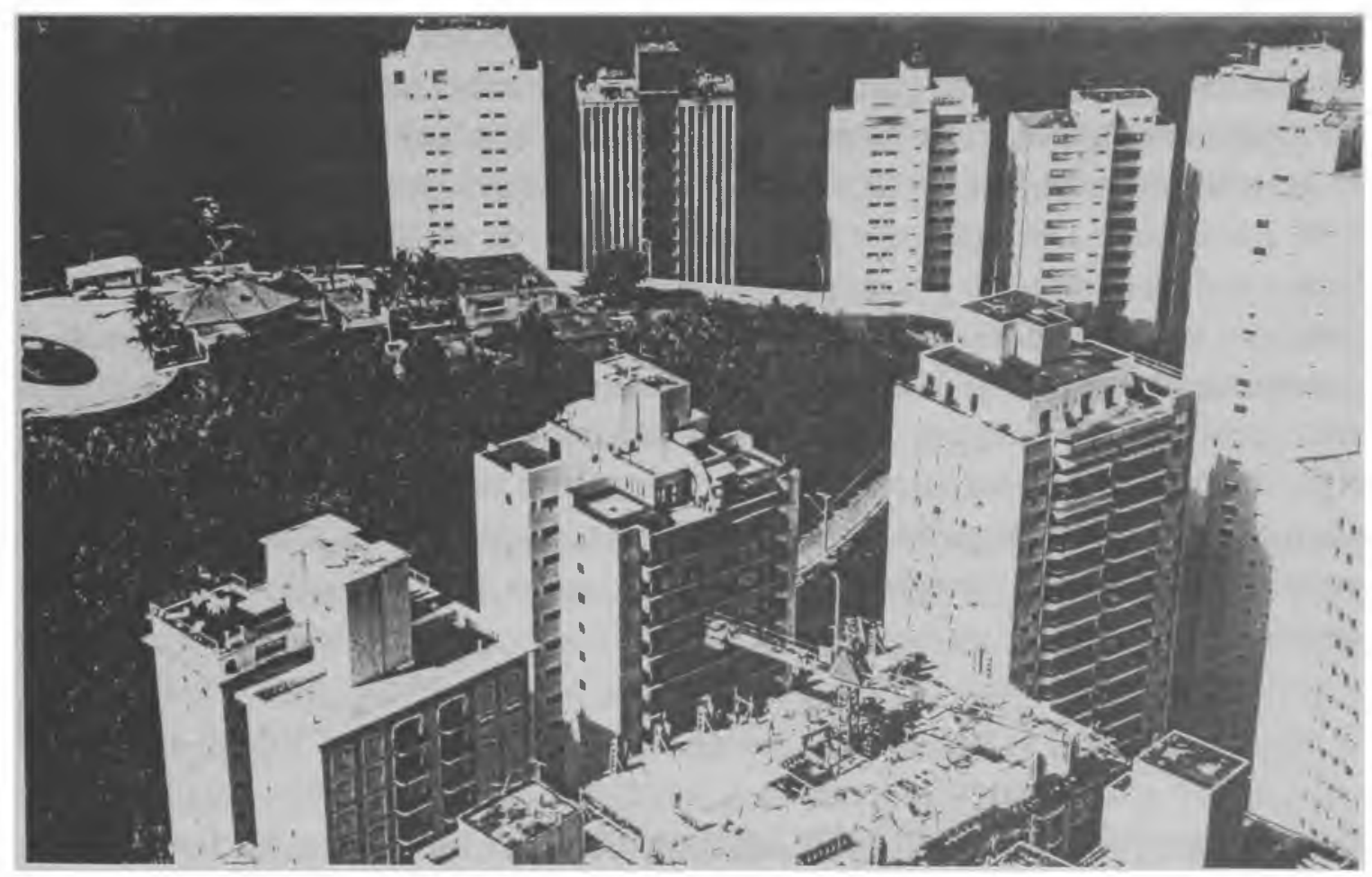

Os prédios edificados no entomo do morro nāo sāo construídos. de modo a se fundir con o meio ambiente existente e transponam para o litoral. para a prox imidade de suas encostas o padrào construído. e que se aplica mais adequadamente a outras áreas mais planas. 
Após cada obra pronta, resulta um prédio sobre terraço, sob o qual se acham as garagens, com piscinas e jardins suspensos, configurando um arremedo ao mar comprometido ecologicamente e a mata destruída.

O sistema viário existente, basicamente uma rua bordejando o mar. exige e exigiu para sua construção, sérias intervenções morfológicas na estrutura do morro. A referida rua, com seus muros de arrimo está implantada quase que totalmente sobre o costão rochoso. Este costão, corresponde à faixa litorânea de contato terra-mar, submetido a oscilações dos níveis de maré e à ação abrasiva das ondas e abriga uma comunidade biológica característica: a comunidade intermareal.

A proteção destes costões porquanto se faz necessária tanto por valores de segurança, como por valores ecológicos a manutenção da vida desta comunidade muito diversificada, e cuja existência é fundamental para a cadeia ecológica litorânea:

\section{MORRO DO SOROCOTUBA}

O Maciço de Sorocotuba é um exemplo claro, no seu conjunto, dos diversos momentos do processo de predação vigente nos costões de nosso litoral. Valores ecológicos excepcionais, cênicos e portanto turísticos são dilapidados em função de padrões de implantação de loteamento e de arquitetura restritos, que envolvem para sua construção eficientes tecnologias de destruição. Poucos são os locais onde a edificação possui pelo menos alguma intenção de convivência com o meio e quando isto acontece, é de uma maneira pontual e talvez, ocasional. A construção maciça de prédios só favorece seus proprietários. Quanto maior for a área recoberta por construçōes, menos será a característica excepcional do lugar e portanto seu valor turístico. Quanto maior for a população, mais cara e complicada será a manutenção da qualidade das águas devido a obras de saneamento especiais que requerem, e portanto, mais restrito será seu uso para recreação e lazer...

O plano municipal existente, que designa o morro como Zona Verde, ainda tem um caráter extremamente genérico e necessita de um urgente detalhamento. Deve-se reverificar os padrões de assentamento das novas construções, infelizmente aprovadas sem nenhum critério ecológico de modo a se deter com urgência o desaparecimento de boa parte do patrimônio ambiental do morro, um verdadeiro patrimônio ambiental urbano. $\mathrm{O}$ morro pela sua posição de enclave no município, deve ser valorizado ao uso, mas deve ter sua ocupação mais 
rigorosamente planejada, de modo a evitar os constantes danos que vem sofrendo e talvez possa, se estruturado para tal, fazer parte de um sistema real de áreas "ditas verdes" parque de apoio a vida urbana e ao turismo.

\subsection{Relevo e Cobertura Vegetal}

O Morro do Sorocotuba apresenta suas vertentes ou encostas com declividade elevadas, geralmente acima de $30 \%$. As rochas que o sustentam são de elevada resistência, pertencem ao grupo das cristalinas de origem metamórfica. São principalmente migmático e gnaisses. Sobre esta litologia desenvolvem-se solos de profundidades variáveis, cujas características texturais são dominantemente argilosos e siltosos. Em alguns segmentos do terreno os solos praticamente desaparecem, dando lugar a afloramentos rochosos. Entretanto. o mais freqüente é a ocorrência de manto de alteração espesso com os solos apresentando os três horizontes bem marcados.

O trabalho dos desmontes com obras de terraplenagem, a execução de obras de arte com cortes, e aterros, retira a camada superlicial do solo. Isto expõe à ação climática as camadas mais profundas. Esta parte do solo guarda muitas características mineralógicas e físicas da rocha matriz. Entretanto. por apresentar uma porção menos trabalhada pela ação dos agentes intempéricos, mostram-se muito menos adaptada a ação das águas e por isso mesmo extremamente vulneráveis a ela.

Este tipo de ação tem dois momentos muito distintos. No primeiro, gera-se aquela que se denomina como impacto direto e em um segundo momento desenvolve-se os impactos derivados do primeiro.

Os impactos diretos são aqueles usados pelas obras de terraplanagem com desmonte parcial dos morros e encostas, pela execução de cortes e aterros para implantação de ruas e edifícios que acabam por desfigurar inteiramente a paisagem natural e com isto quebrando a harmonia existente entre relevo, solo, vegetação, águas. etc...

Os impactos decorrentes dos primeiros advêm freqüentemente em função de um tratamento inadequado do meio natural que sofreu intervenção humana. Deste modo é muito comum em áreas como a do Morro do Sorocotuba ocorrerem escorregamentos, deslizamentos, desencadeados por processos erosivos agressivos e irreversíveis. Estes eventos acontecem freqüentemente em decor- 
rência da quebra do equilíbrio morfodinâmico devido aos cortes $c$ aterros $c$ inadequados sistemas de tralamento das águas pluviais.

Recobre esse relevo. cujas vertentes se mostram bastante inclinadas, uma cobertura vegetal marciada principalmente por matas. Estas são constituídas por árvores com mais de $10 \mathrm{~m}$ de allura. em que predominam espécies nativas. Em algumas encostas a mala aparece mais preservada da ação humana. Entretanto. em outros locais. a ação antrópica é evidente com sinais de retirada de madeira e palmito. pelo desenvolvimento de vegetação secundária de menor porte e pelas inúmerass cicatrizes de crosões ao longo dos canais de escoamento das águas pluviais.

Em algumas encostas. cujo processo de desmatamento é antigo c as áreas não estão edilicadas. há recobrimento por campos constituídos principalmente por gramíneạs.

Grande parte das encostas encontran-se com sua paisagem frágil em equilíbrio mortodinâmico. làce a estas ações antrópicas.

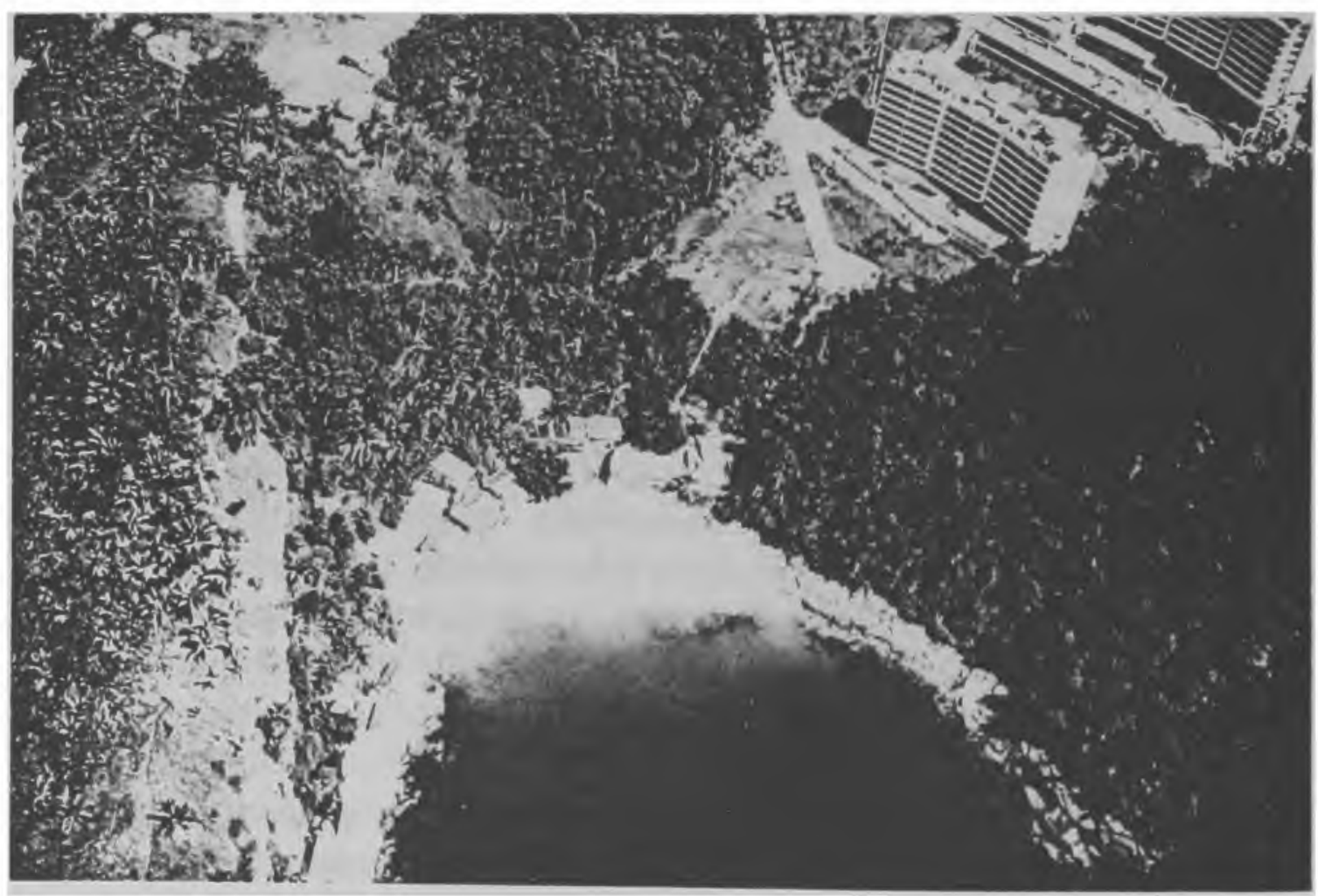

Senviço de terraplenagem. com a execuçāo de cortes, aterros. com desmonte parcial do relevo. expondo os horizontes mais sensiveis do solo. favorecendo atividades erosivas. 


\subsection{Faira Litorânea}

Na faixa litorânca. os processos erosivos. atuantes nas encostas do morro voltadas para o mar. Iendem a produzir assoreamento no fundo de locais menos expostos às correntes marinhas. Determinações do coeficiente de extinção da luz na água em inúmeros pontos margeando as costas do morro indicaram que as pequenas baías nos lundos das quais existem as poucas praias da região. são as áreas que mais estão solrendo com as movimentações de terra produzidas direla ou indiretamente pelos empreendimentos. Nestes locais é visível mesmo a olho nu uma quantidade de argila em suspensão na região de arrebentação, indicando o assoreamento. isto é. a cobertura por lodo do sedimento arenoso original.

Com relação à fauna c llora dos costões e praias da região, os organismos que estão sujeitos a maior stress são os organismos-filtradores de ventos das praias arenosas que sofrerão alterações irreversíveis em suas populações.

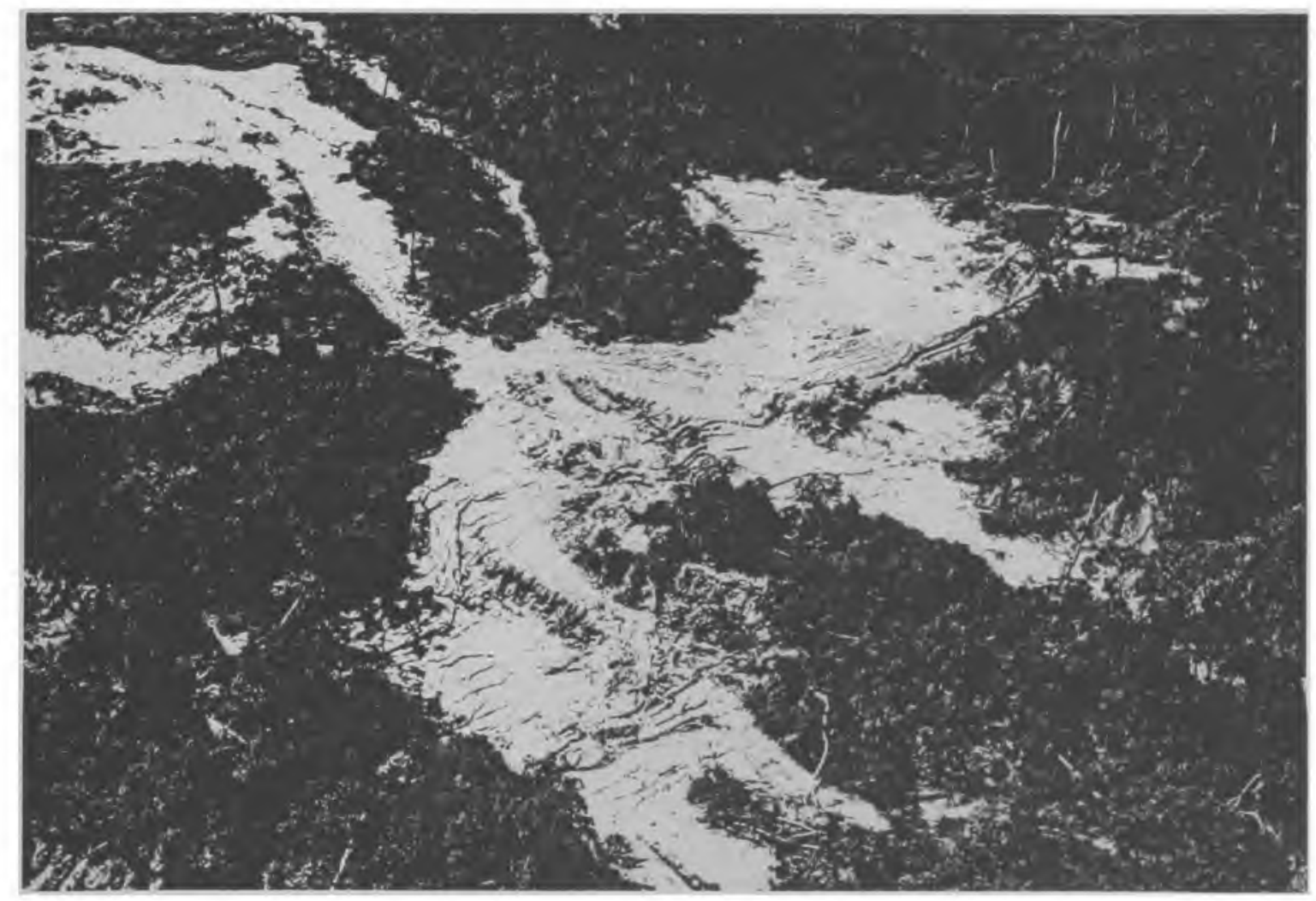

Vista do fundo da pequena enseada no setor (04). onde se observa o recobrimento da areia da praia por sedimentos tïnos (silte e argila) provenientes das atividades a montante do morro. 
O grande número de unidades habitacionais em edificação produzirá uma carga de esgotos significativos, cuja disposição final será nas águas litorâneas adjacentes. Estas águas terão suas condições de balneabilidade afetadas, assim como seu uso para esportes de contato direto tais como esqui aquático. surf, etc... No Morro do Sorocotuba existe um criadouro de moluscos cuja exploração será prejudicada uma vez que estes animais são filtradores e irão concentrar microorganismos patogênicos provenientes dos esgotos dos edifícios vizinhos, podendo vir a constituir-se em fonte de moléstia.

\subsection{O Processo de Ocupação}

O maciço de Sorocotuba apresenta-se com todas as formas de ocupação citadas da mata natural do vale, ao paredão de torres construídas sobre vastos planos edificados. Pode ser dividido em alguns setores, de acordo com diferentes níveis de ação antrớpica:

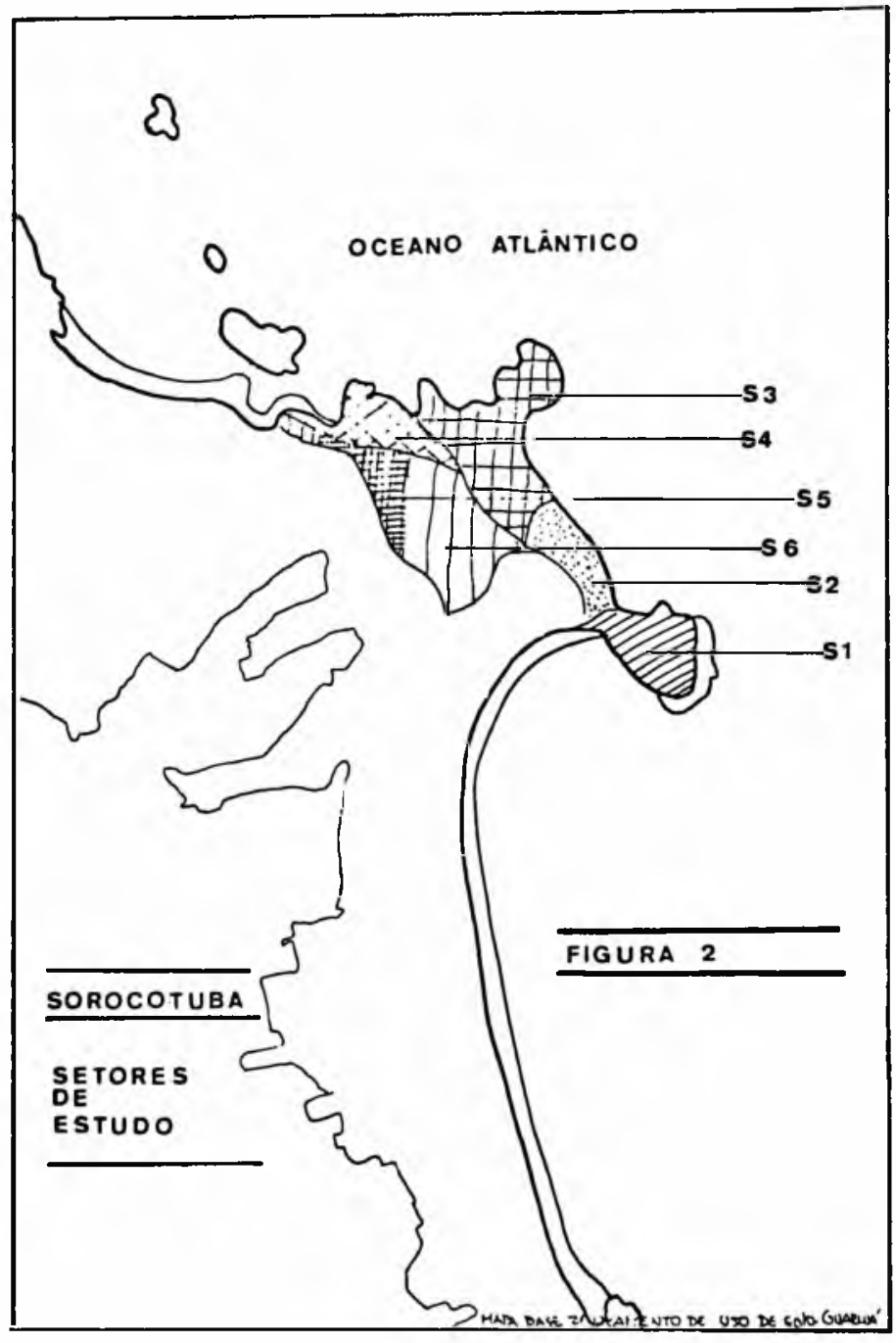


SETOR 01 Vizinho à Praia da Enseada (Morro da Península) As encosias encontram-se totalmente urbanizadas, com lotes muito construídos e arborizados. O terreno está praticamente todo trabalhado em terraços com alguns cortes pronunciado. Em termos visuais. o morro mantém a sua escala primitiva. já que as construções pouco ou nada sobressaem a copa das árvores. A vegetação é praticamente toda replantada. nada restando da cobertura original que foi devaslada para a construção das residências e das vias de accsso.

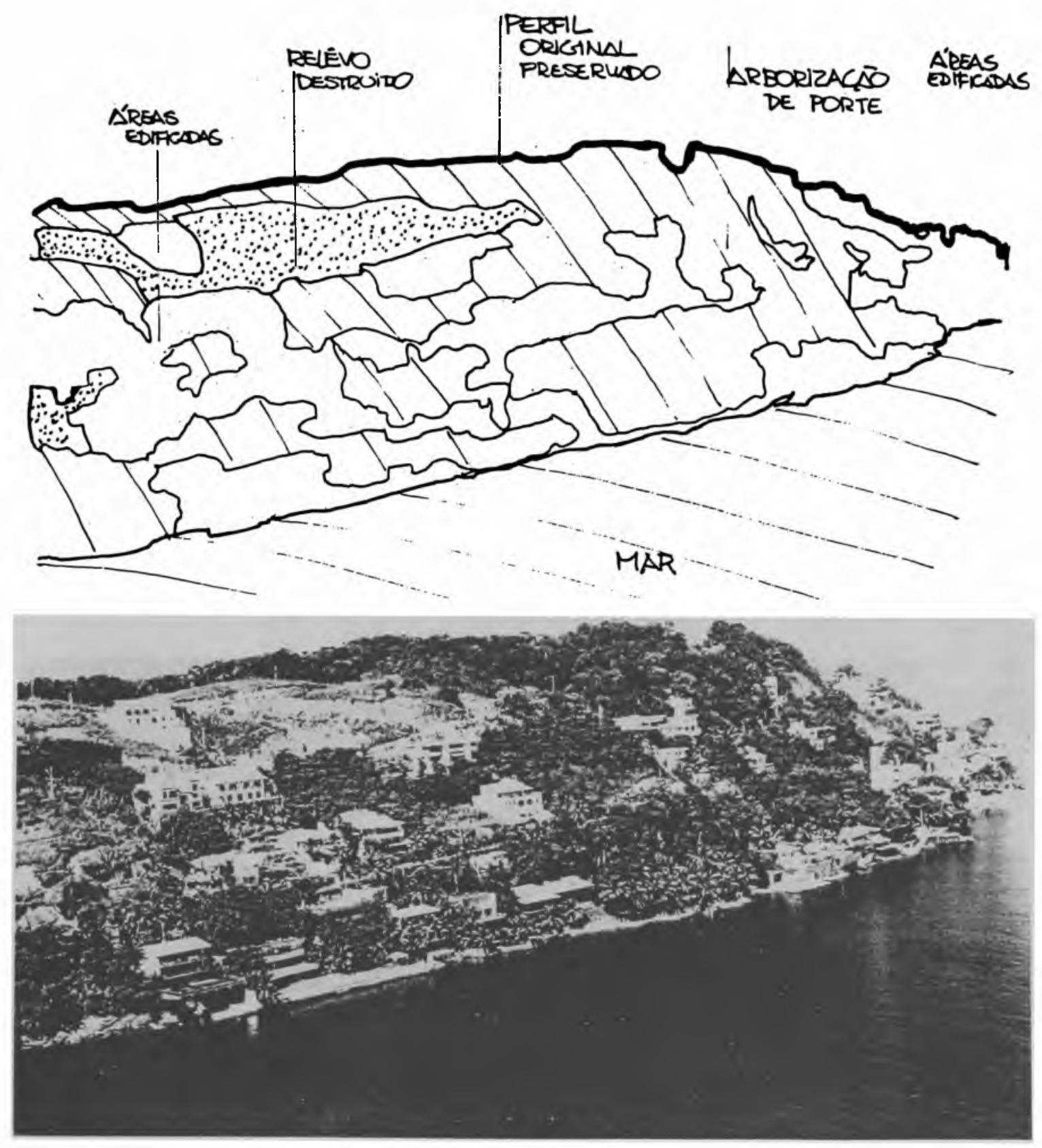

Vista geral do setor $(01)$. A construçāo dos caminhos do Ioteamento exig̣iu contes profundos no morro. com sinais cridentes de erosīo. 


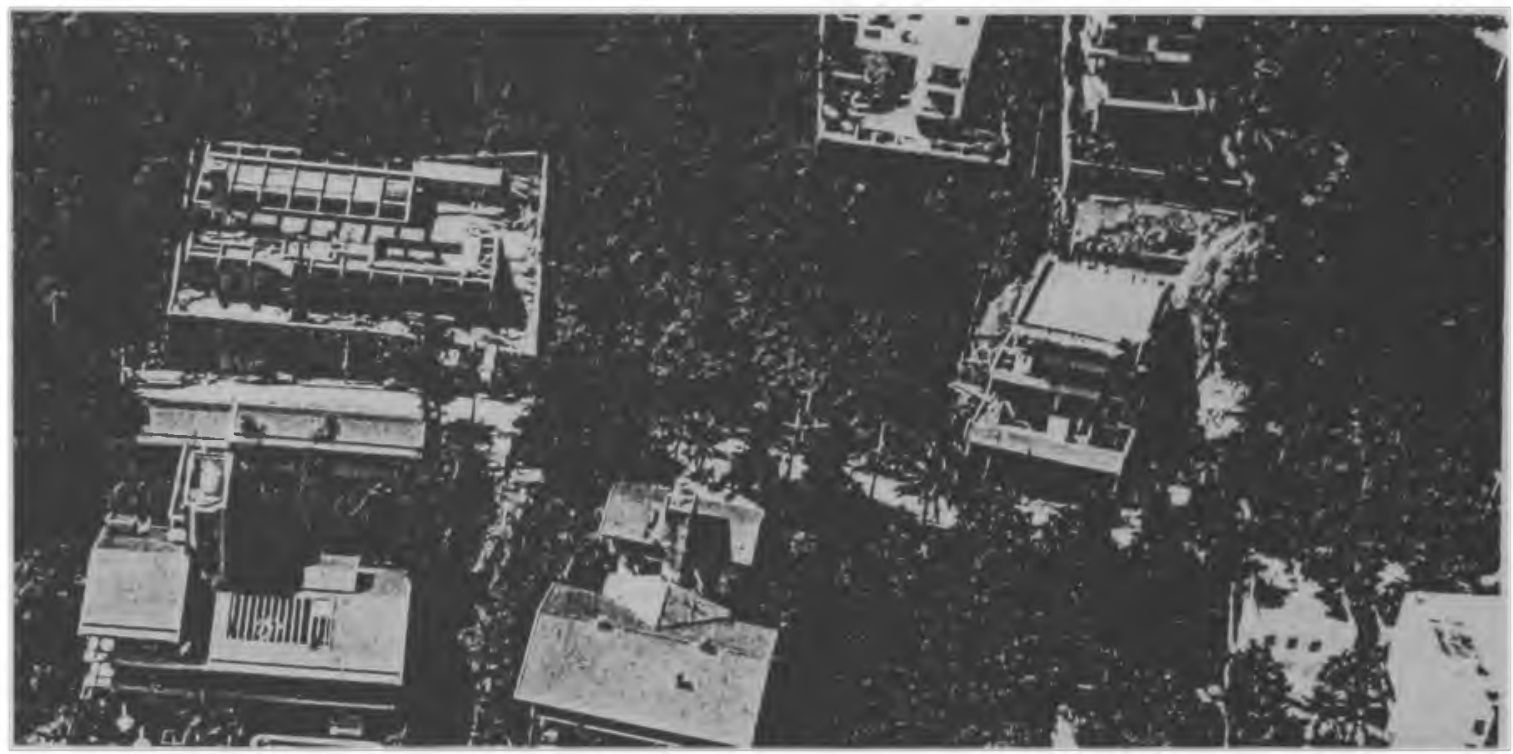

Cada nova edificação. reconstrói a encosta do morro. criando novos terraços, que en contraponto à siluazção obien ada no Morto do Maluf mantém a sél modo a estrutura moriológica do conjunto (ao menos visualmentel. É de qualquer modo. uma ocupação intensiva do lote que tem seu terreno totalmente recomstruido e está quase inteiramente revestido por lajes.

SETOR 02 O denominado Costão das Tarlarugas. Encontra-se parcialmente ocupado por edifícios de apartamentos de quatro c mais andares. E está. como loda a área restante. comprometida com novos empreendimentos. Todas as edificações. cujas formas c volumes sĩo típicas de terrenos planos. exigem grandes movimentos de terra para sua implantação. com o conseqüente comprometimento da qualidade ambiental: desmatamento. poluição do mar. c a desIruição do relevo do morro e do costão (junto à linha da maré).

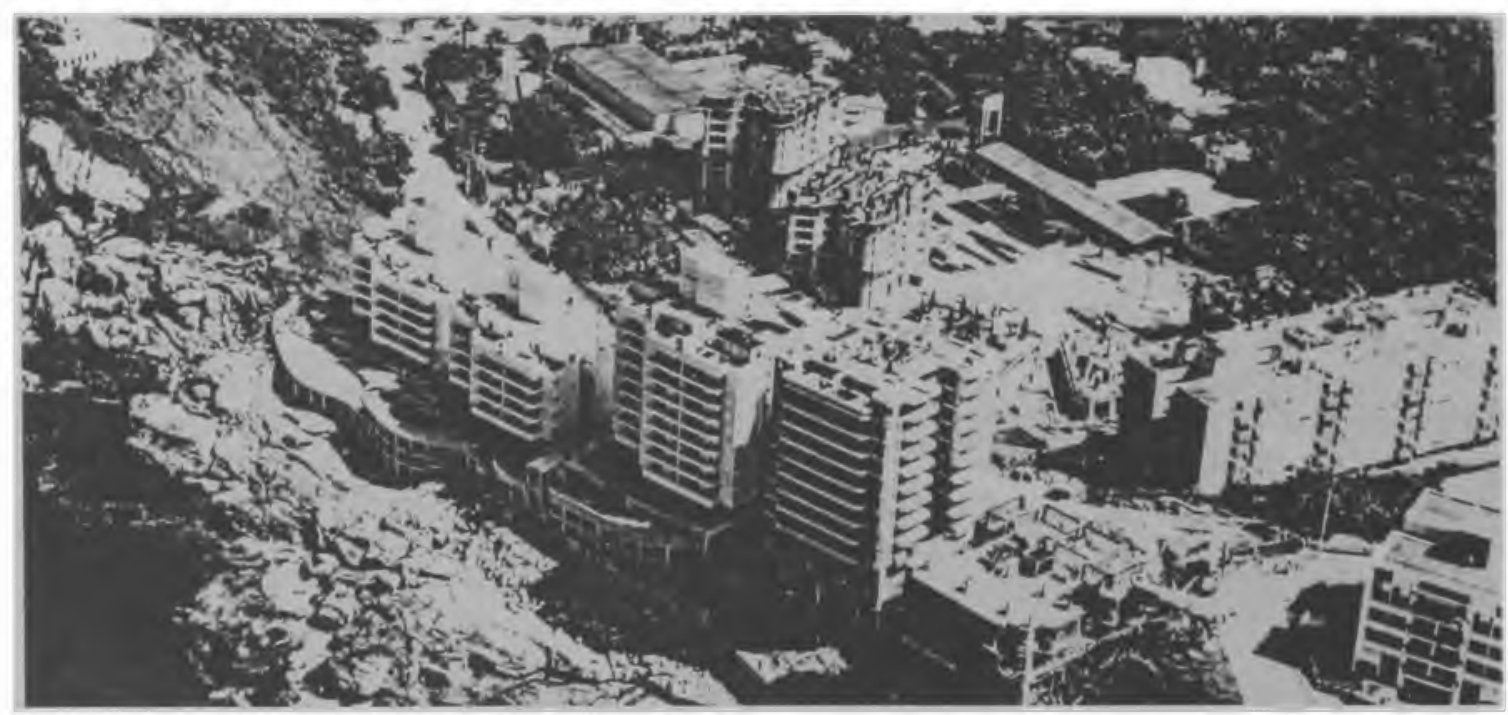

As novas torres setor (02) nāo respeitam a rica estrutura do costāo existente e constróen sobre ele. Os edifícios para sua perteita construção exigem a criação de terraços e neste local se repete a foma predatória de ocupação do Morto do Maluf. 


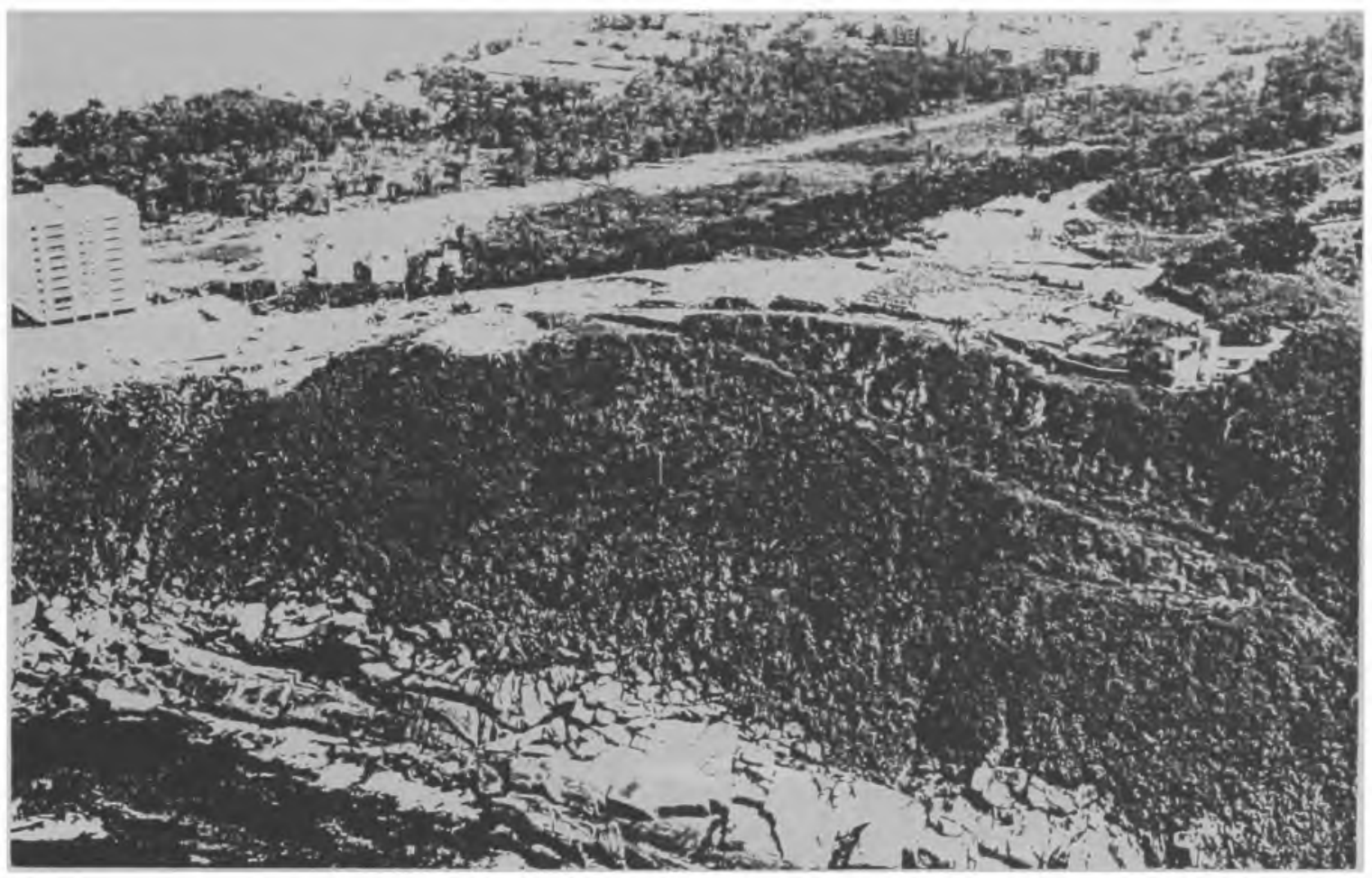

Este setor é un dos mais comprometidos pelo padrão de urbanização adotado. O terreno está sendo cada vez mais terraceado perdendo sua configuraçāo original de relevo c suas matas.

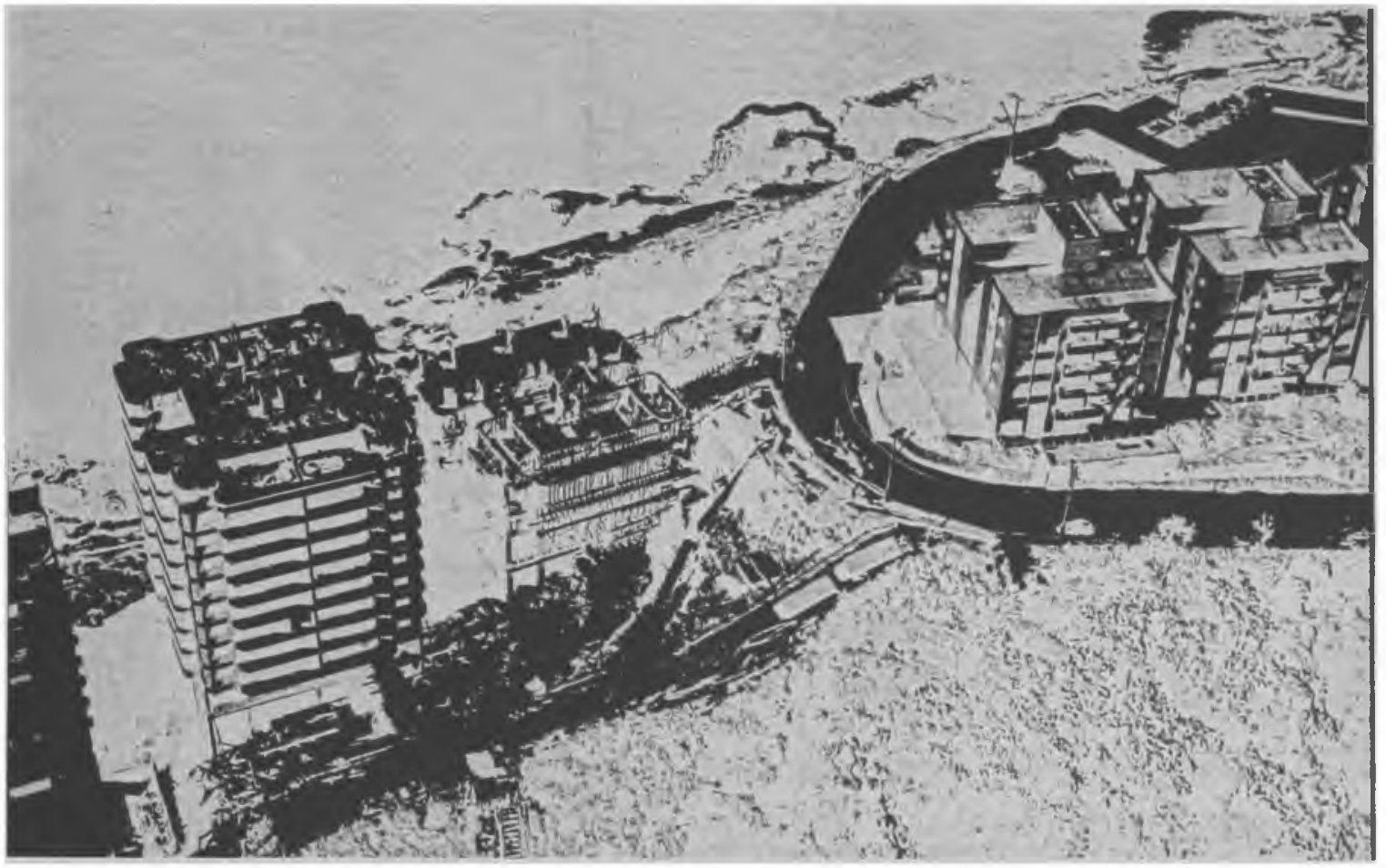

Nas vizinhanças do conjunto de prédios en construção, um vasto sctor de morro já terraplenado praticamente pronto para receber novos edifícios. 
A sua forma de implantação está pouco a pouco criando uma verdadeira barreira de acesso aos bordos do costão. bem como criando um novo perfil do morro. A arquitetura se fecha em si. mantendo apenas relações tímidas com o entorno. As garagens e planos de apoio dos edifícios se sobrepõem aos limites pedregosos do costão. destruindo estruturas físicas e ecológicas importantes. cnquanto que o segmento de mar fronteiriço apresenta uma qualidade de água menos adequada para esportes náuticos c pesca. com conseqüente aumento da poluição e diminuição da diversidade de vida animal.

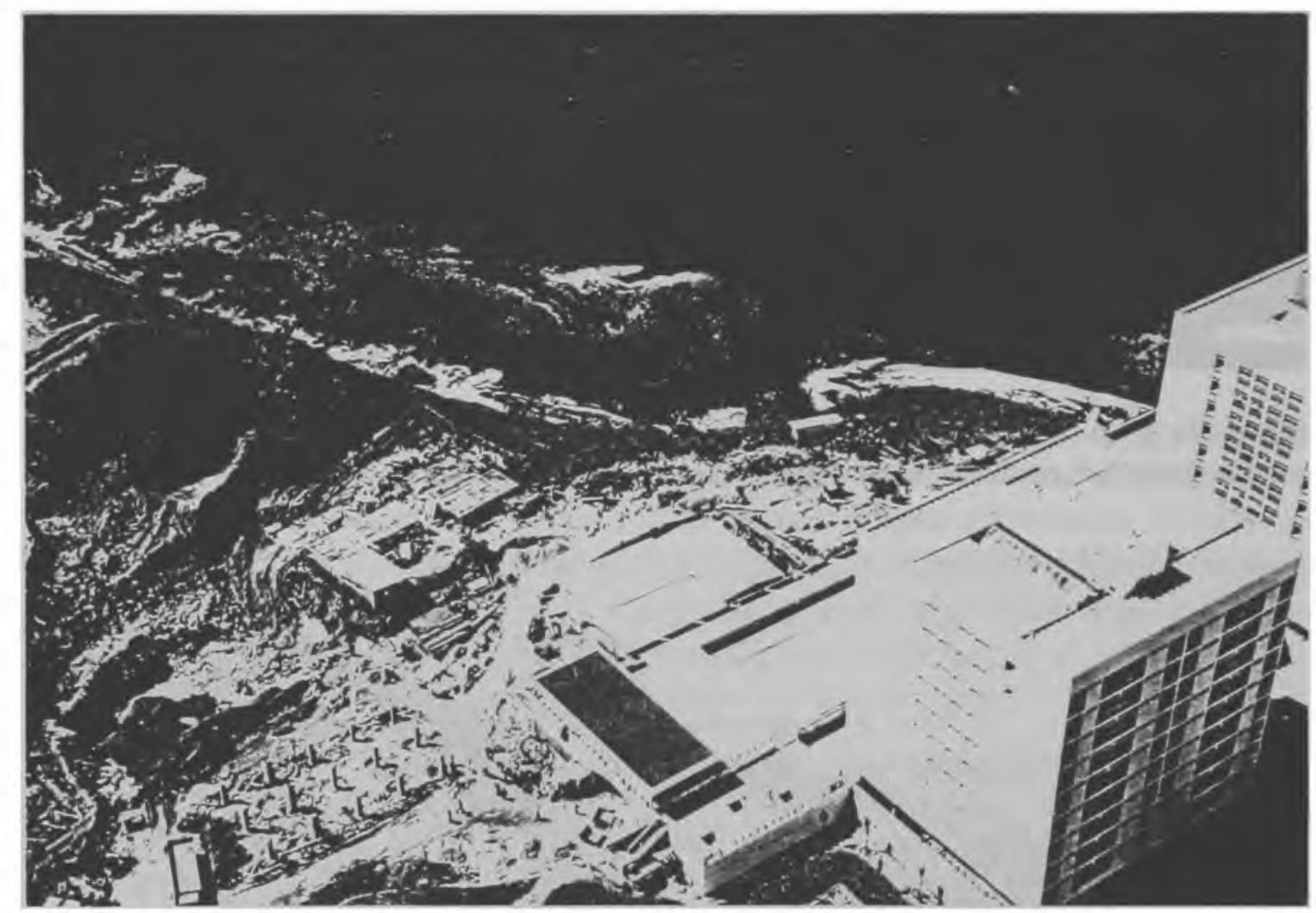

Este é un local de difícil acesso ao mar. que não se presta para banhos e sim para pesca e espontes náuticos. Os prédios se isolam em si. desprezando-se os "danos ecológicos" causados pela sua presença no mar vizinho.

SETOR 03 As encostass apresentam-sc quase que tolalmente ocupadas por malas naturais em cujo meio a intervenção antrópica é incxpressiva: - apenas existem alguns trilhos de acesso ar-mar e uma outra edificaçĩo. É com certeza. a área mais propícia para o desenvolvimento de um turismo moderado. devido as amplas possibilidades que oferece ao homem de convívio com matas $\mathrm{e}$ mar com maior diversidade e riqueza de vida. o que se expressia visualmente através de uma paisagem muito rica. com mar limpo e malas luxuriantes. 

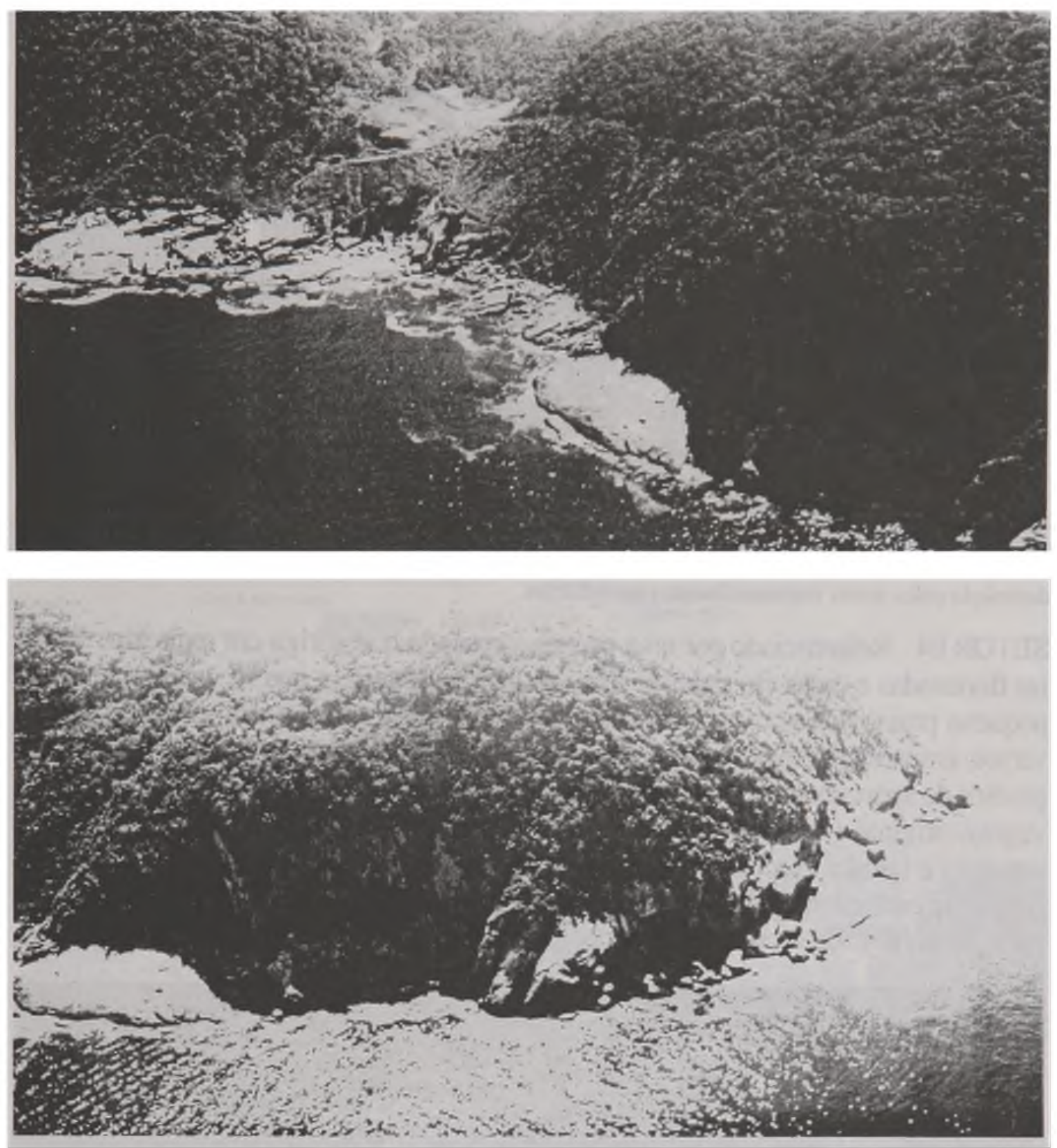

De todo o costāo do Morro de Sorocotuba o setor (03) é o que apresenta sua estrutura morfológica mais próxima da sua foma prinitiva. As matas apresentan-se quase que en equilíbrio ecológico completo. devido a pequena intetvençāo antrópica existente e o mar apresenta excelentes condiçōes de uso.

Esta situação, praticamente encravada dentro do tecido urbano, que se espalha qual mancha de óleo pelas cosłas do Guarujá. por sua excepcionalidade e beleza. com certeza deve ser preservada e utilizada para recreação e lazer da população. Pela sua localização, assume praticamente as características de um "Parque Urbano Especial". A fragilidade dos ecossistemas abrigados nesta área sugere, entretanto. que qualquer utilização seja feita dentro das mais estreitas normas de segurança ecológica. 


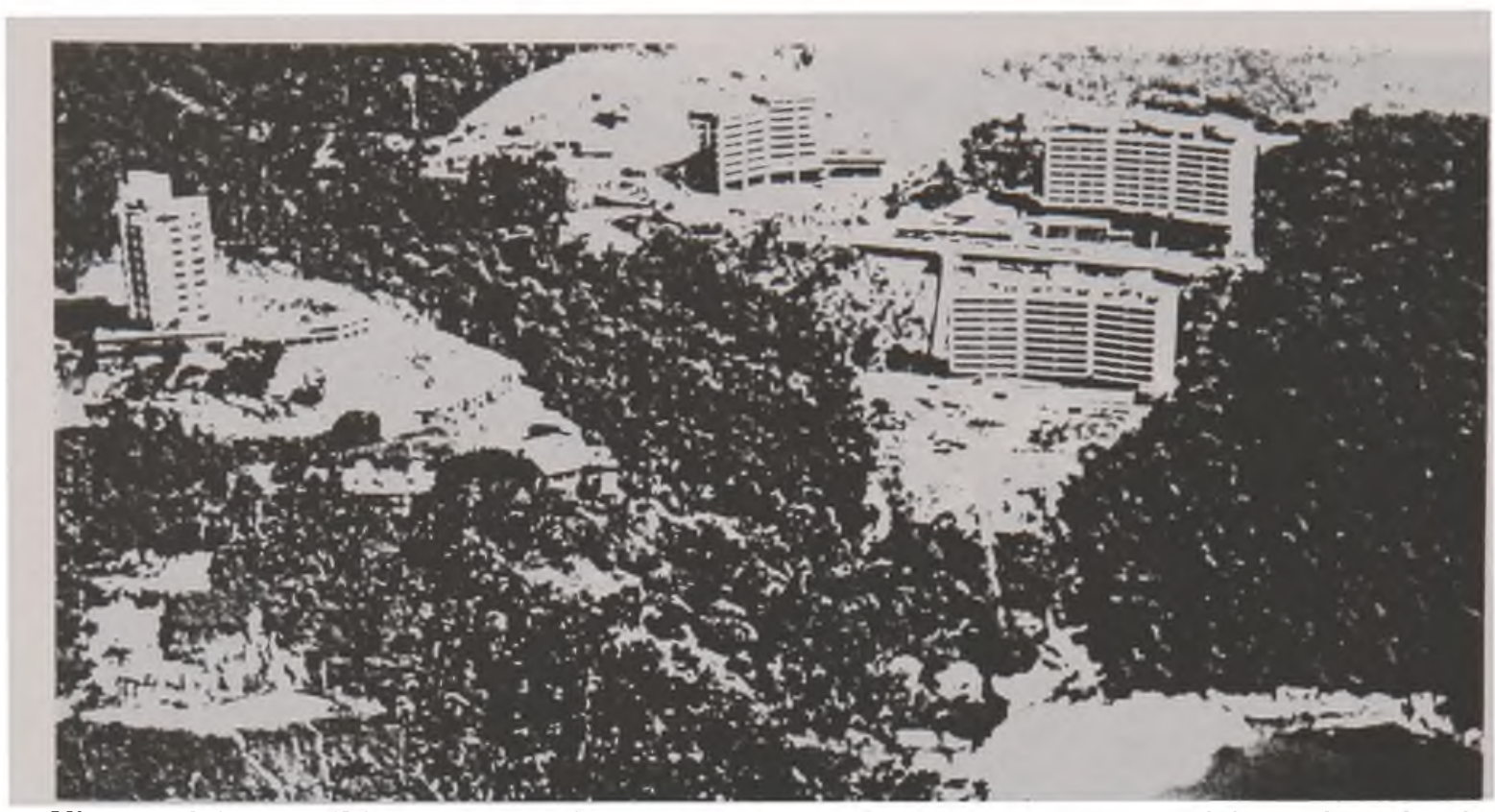

Vista geral do setor (04), segmento até a pouco coberto por matas em processo parcial, mas intensivo de destruição pelos novos empreendimentos imobiliários.

SETOR 04 - Referenciado por uma pequena enseada que abriga em anfiteatro encostas florestadas e casas em palafita sobre as pedras do costão que se voltam para uma pequena praia. Nas suas vizinhanças, o topo dos morros está sendo ocupado por diversos empreendimentos imobiliários que, em função da construção de diversos prédios de apartamentos, destruíram e estão destruindo, vastas extensões de cobertura vegetal original (mata), substituída posteriormente por extensas lajes e terraços de concreto e taludes recobertos de gramíneas. Sobre parte da linha d'água do morro (calha de escoamento) foi construído um acesso à praia com os evidentes prejuízos para a estabilidade do sistema de escoamento pluvial.

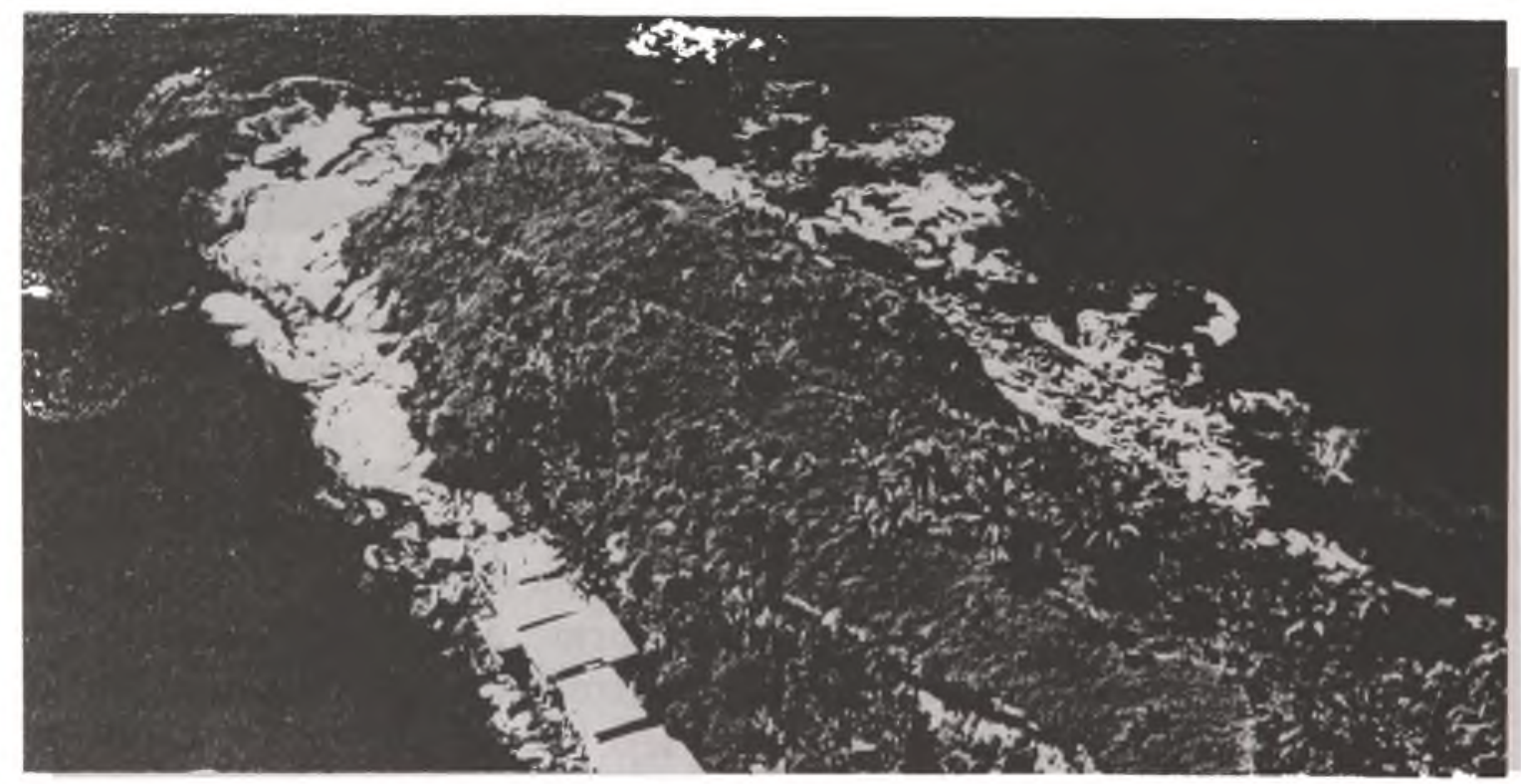

Detalhe da pequena enseada que baliza o setor (04) com suas pequenas construções sobrepovias delicadanente sobre o costão. 

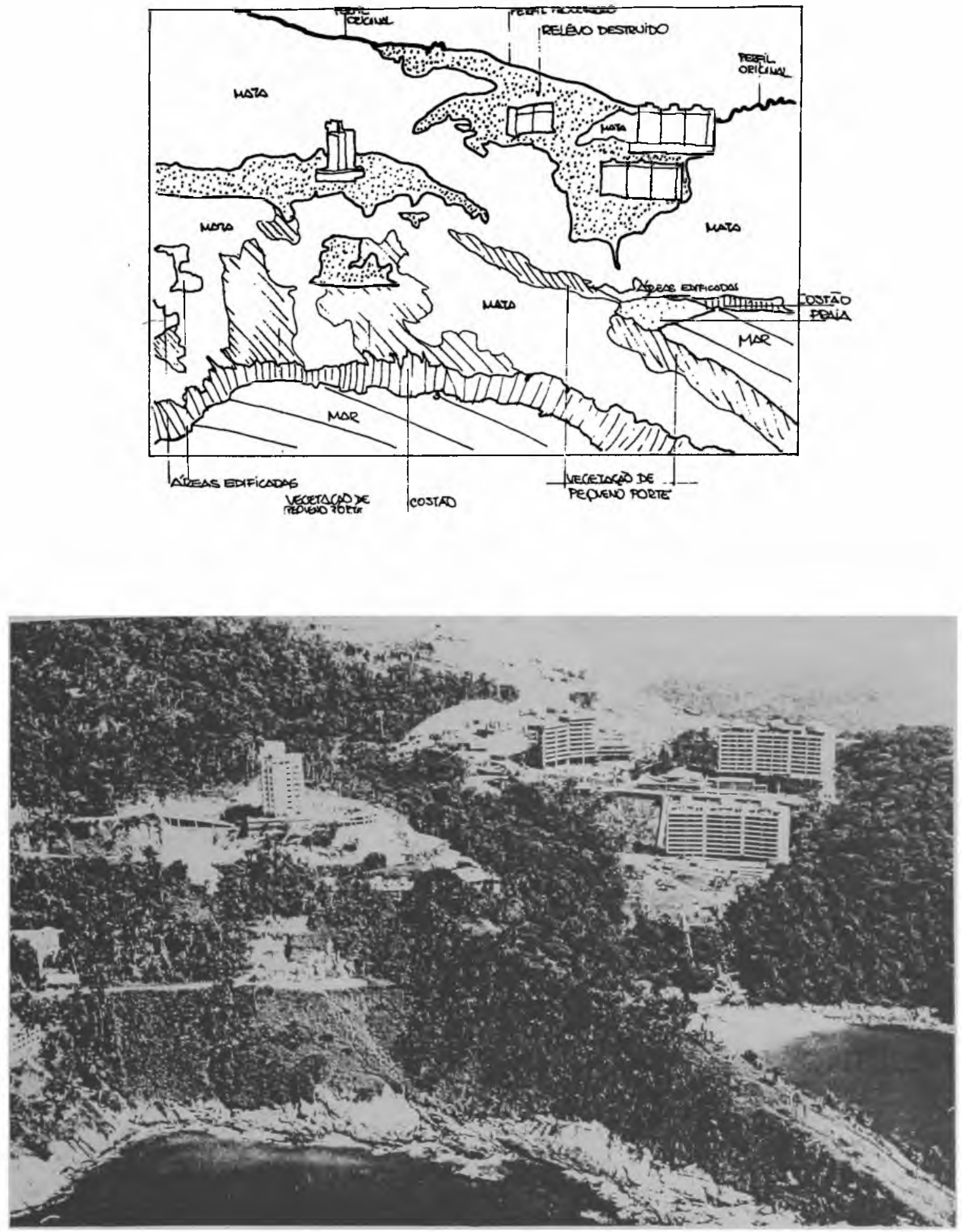

Esta vista do setor (04) mostra as diversas fomas de assentamento de edifícios de apartamentos e casas, estas últimas sempre respeitando de um modo menos rude a encosta existente. Os cortes necessários para sua construção e das vias de acesso são muito drásticos e o terreno apresenta teṇdências a processos de erosão. 
De todos os setores este é o que mais sofre atualmente com um processo de urbanização descompromissado com o meio em que está inserido. Outra vez. como no Costão das Tartarugas, os edifícios não têm projetos de implantação que permitam a sua convivência com o ambiente que é destruído muito mais do que seria necessário para sua construção. $O$ porte dos cortes e aterros necessários para a construção dos planos horizontais sobre os quais serão implantados. somados ao efeito direto dos canteiros de obras. compromete nitidamente 0 equilíbrio ecológico existente. As matas pouco a pouco são destruídas e como se sabe terão uma difícil e quase impossível regeneração. Estes edifícios são produtos de uma lei efêmera (n. 1.555 de 26 de junho de 1981 - Prefeitura Municipal do Guarujá) já revogada que permitiu a aprovação de tais construções, em que os critérios de assentamento pouco ou nada considera as situações pré-existentes causando os efeitos mencionados.

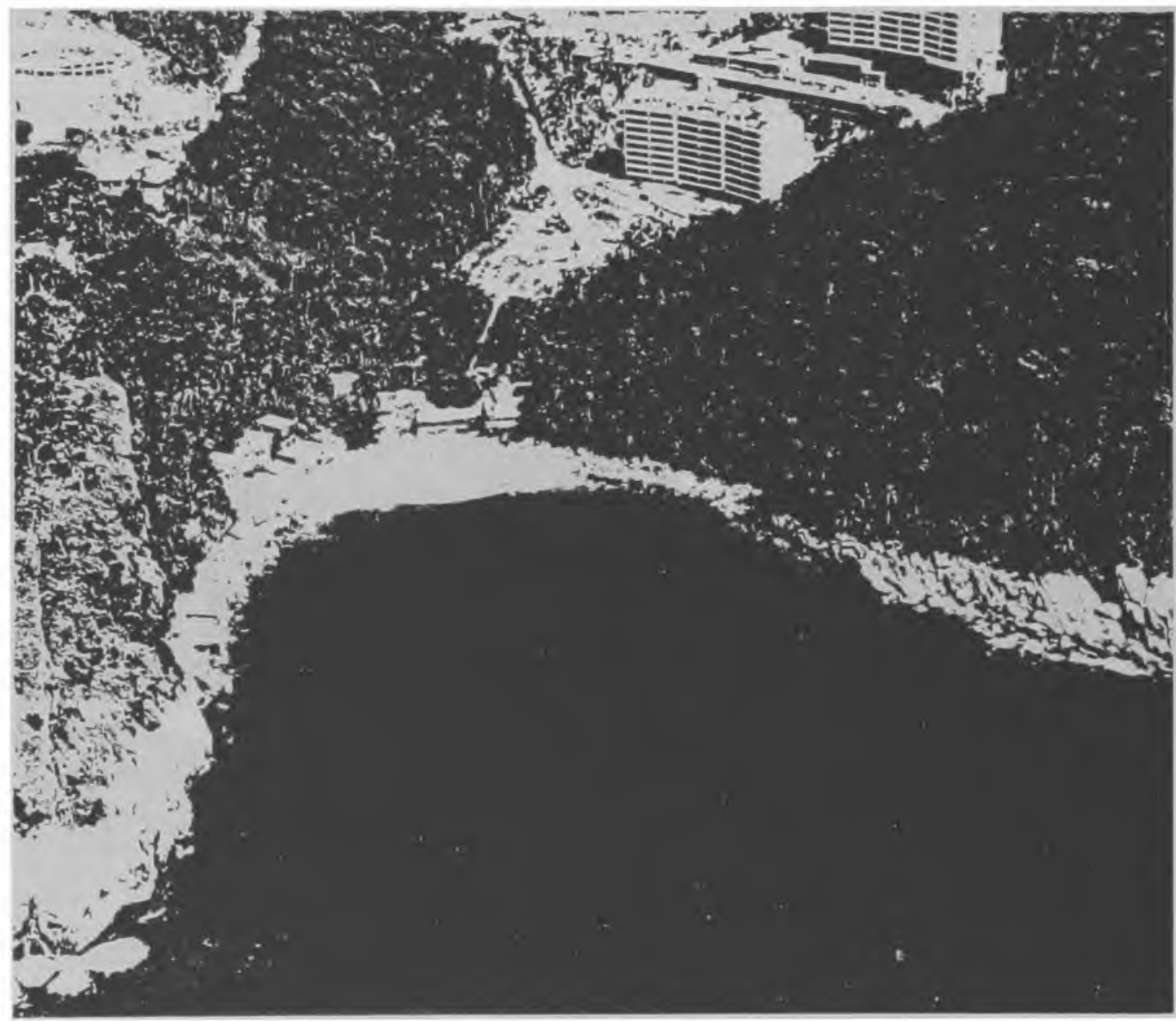

A linha de escoamento de água do morro está parcialmente ocupada por terraços de acesso à praia do novo empreendimento imobiliário. 
SETOR 05 O lado do morro oposto ao setor 04, cujas vertentes dão para o interior apresentam situações de mudança radical da sua estrutura física devido aos violentos movimentos de terra e desmatamentos que aí se processam. Outra vez se repetem aqui, de um modo intenso, situações encontradas nos setores 02 e 04 com todos os danos decorrentes. abrindo-se caminho à erosão. a homogeneiżação da cobertura vegetal e diminuição da diversidade da vida animal fatos estes tão prejudiciais ao equilíbrio ecológico.

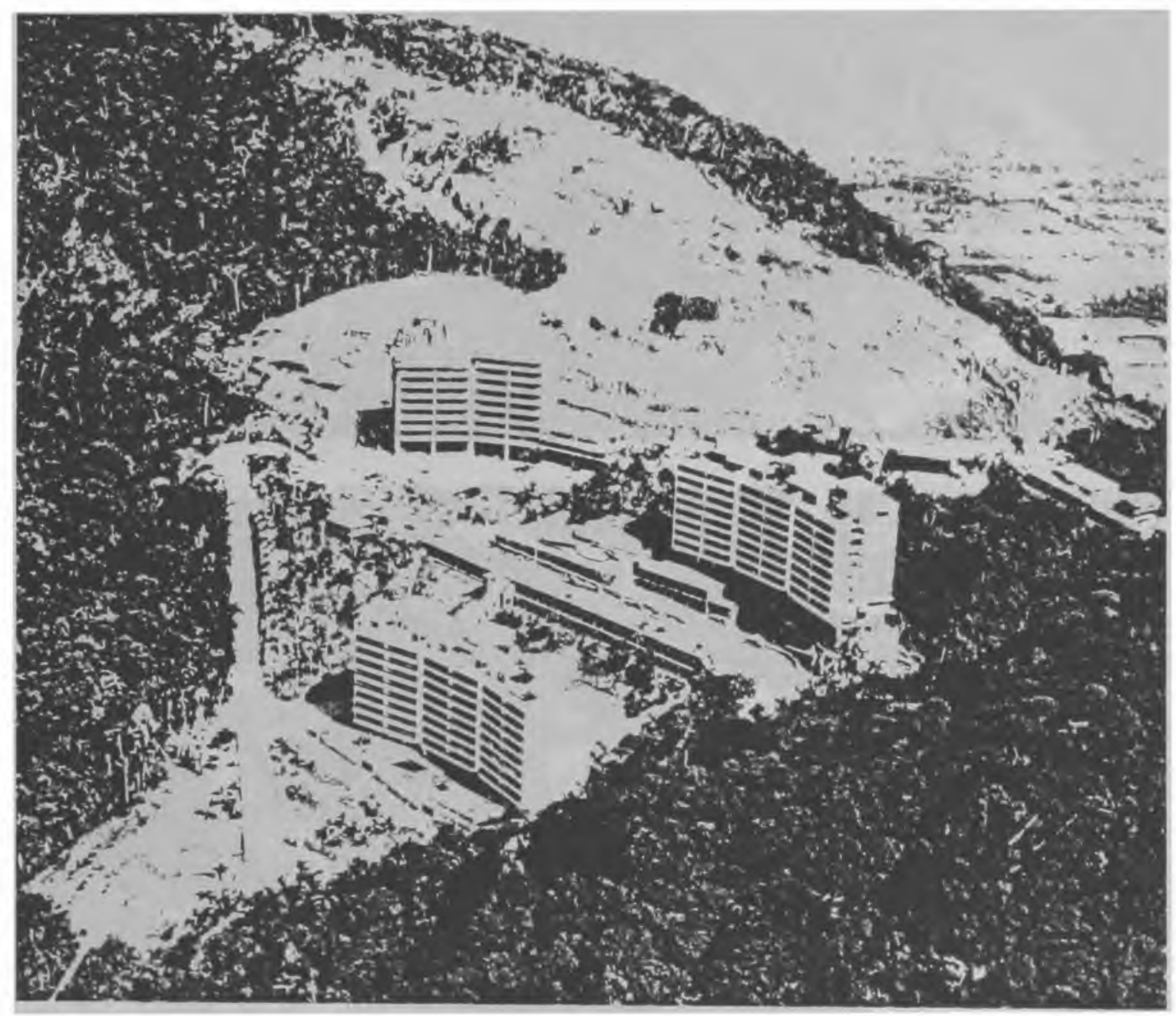

O novo empreendimento imobiliário para a colocação de seus poucos edifícios arrasa e arrasou vasta área da mata, que é substituída por gramíneas...

SETOR 06 - Compreende toda a parte do maciço oposta ao mar, ainda ocupada na sua quase totalidade por matas e que à semelhança do setor 03 apresenta um equilíbrio ecológico maior devido ao baixo índice de intervençāo antrópica, com um elevado valor cênico e paisagístico. 

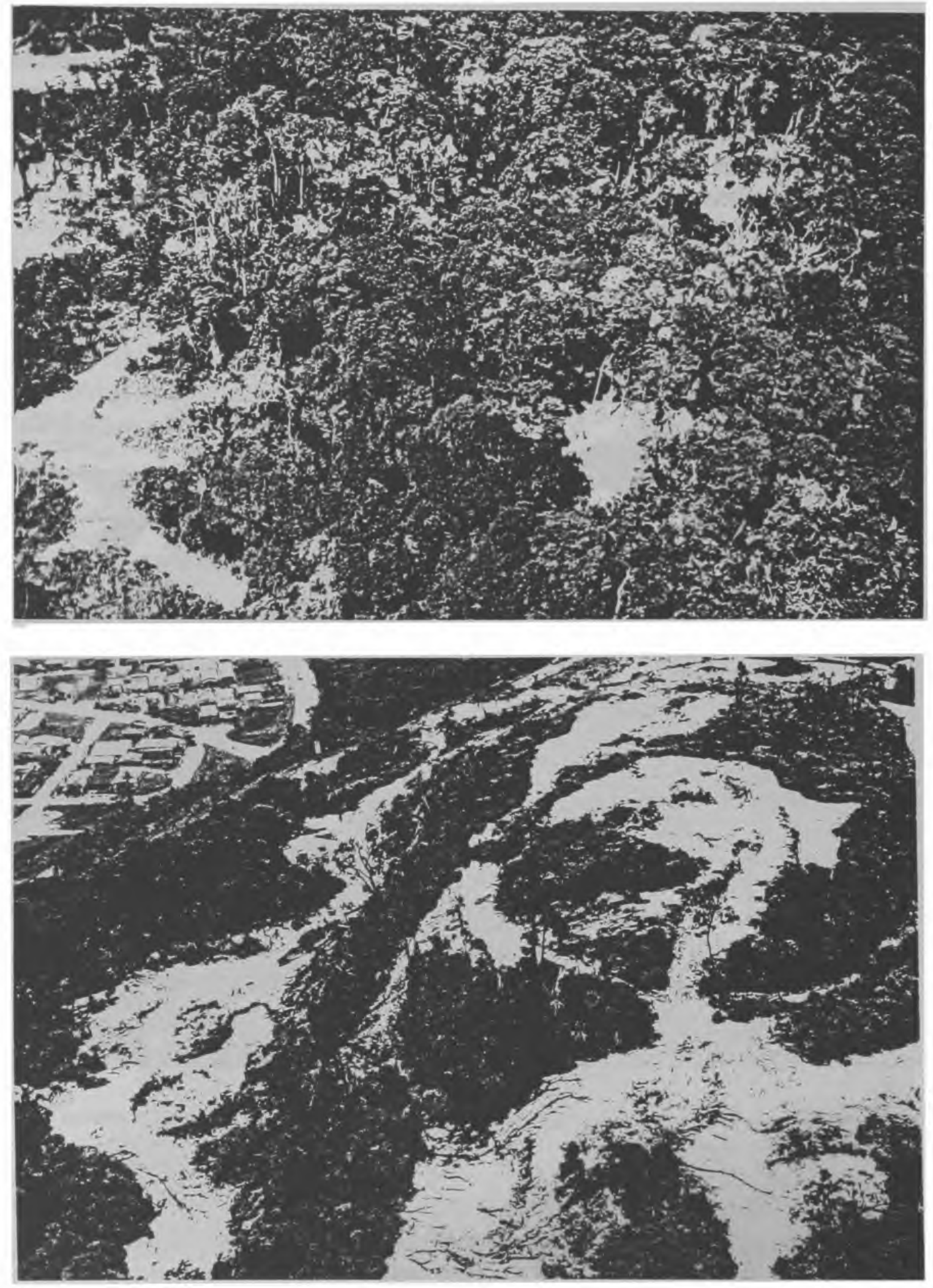

No setor (05) o desmatamento e o terrapleno são intensos e comprometem grandemente o equilibrio ecológico existente. 


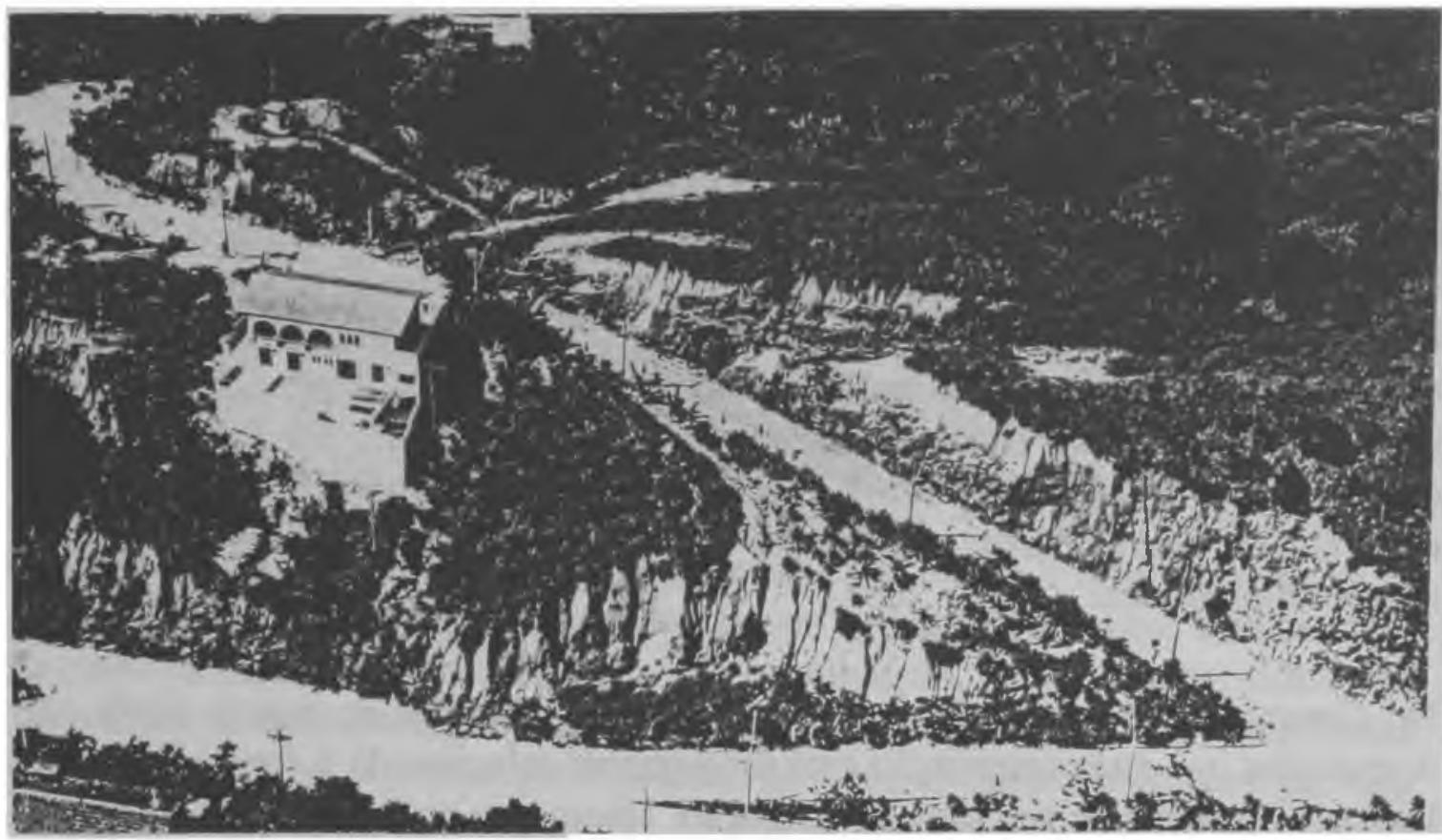

A cada nova construção de edifícios ou estradas repetenz-se os danos à estrutura do morro, que por processos posteriores e lentos de crosão. pode vir a prejudicar o próprio equilibrio de tais construçōes (imagens vizinhas ao Morro da Península).

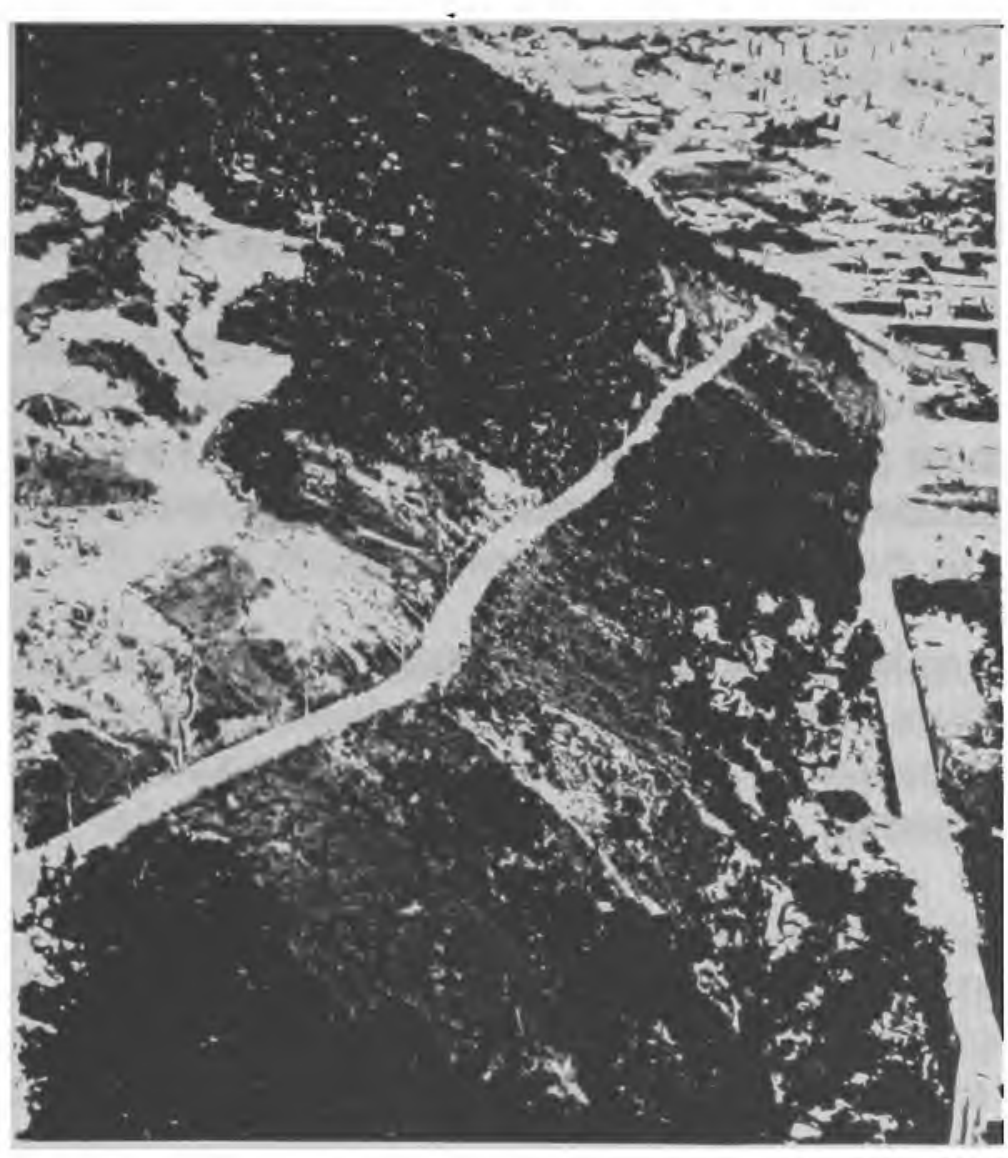

Vista geral do selor (06) ainda en grande parte de sua extensão ocupada por matas. 


\section{DIRETRIZES E RECOMENDAÇŌES}

A ocupação e as atividades turísticas poderiam aproveitar melhor os espaços dos terrenos arenosos das antigas restingas e antigos tômbolos. Seria o caso das formações arenosas e fluviomarinhas à retaguarda do morro do Sorocotuba, da Praia da Enseada e a de Pernambuco, deixando livres os manguezais e as encostas de morros e maciços como reservas florestadas. As depressões de solos orgânicos úmidas, por entre os terrenos arenosos (só identificáveis em reconhecimentos de campo), às vezes bastante brejosas enquanto não drenadas, deveriam constituir áreas reservadas às atividades de horticultura para 0 abastecimento local.

No Guarujá, alguns morros e maciços possuem manchas de matas ainda não derrubadas, e a sua preservação está diretamente relacionada à forma de parcelamento do solo e de sua taxa de ocupação. Mesmo no caso do Morro da Península, no qual a melhor preservação se deve à ocupação por habitações unifamiliares em lotes de grande área, não se garante que no momento da construção se tenha o cuidado de se orientar as calhas ou canais artificiais pluviais de modo a não se perturbar o caminho natural de descida do escoamento pluvial em direção ao mar, ou à rede de drenagem mais próxima, nem a manutenção periódica das encostas e das calhas artificiais de escoamento pluvial.

Estas manchas de matas remanescentes deveriam funcionar para os segmentos urbanizados adjacentes, como um sistema de parques de preservação, de uso restrito, concorrendo para uma melhoria das condiçōes do suporte ecológico, em suas interfaces com as áreas alteradas e os corpos d'água. Outra função relevante que estas áreas florestadas poderiam assumir seria o de promover a convivência do habitante e/ou visitante com o meio natural, de forma que a concientização do seu valor fosse mais disseminada pela comunidade.

A conservação da qualidade ambiental de ecossistemas frágeis e diversificados, como os dos morros e maciços costeiros, exige a regulação dos seus usos e ocupações por um Plano Paisagístico Global que os considere, como deste, partes de uma totalidade regional, descendo até ações locais definidas por projetos setoriais. Todo esse continuum escalar deve estar perpassado pelos critérios de flexibilidade, eficiência, adaptabilidade e imagem de forma a se assegurar a conservação dos valores ambientais existentes, bem como a sua valorização, através do estabelecimento de padrões de ocupação que visem minimizar os impactos ambientais resultantes das intervenções antrópicas. 
A legislação e planos existentes de caráter local, que regulam a ocupação destas áreas, além de não serem verdadeiramente cumpridos, são extremamente vagos quanto à forma de preservação da cobertura original, definindo apenas porcentagens de área a se manter livres de edificações, pouco importando se uma riquíssima associação vegetal característica da mata tropical atlântica seja substituída por um simples gramado. Não se estabelece nenhum critério que norteie sua localização e distribuição. Assim, se torna bastante problemático que 0 estabelecimento das chamadas "Zonas Verdes" nos moldes como foi feito por estes instrumentos locais, resulte em benefícios sensíveis para a conservação de situações ecológicas e paisagísticas importantes, bem como configura formas de ocupação equilibradas e saudáveis. A mesma indefinição e falta de atenção às especificidades locais se revela no trato com os índices urbanísticos tradicionais, tais como as áreas dos lotes, recuos, taxas de ocupação, gabaritos das edificações e previsões de demandas por serviços e infra-estruturas, que da mesma forma relevam os problemas desencadeados pelas práticas abusivas de cortes e aterros, impermeabilização do solo, alteração no lençol freático e adensamentos inadequados. Estas indefinições levarão fatalmente a situações de congestionamento e saturação do trânsito de veículos de acesso e de circulação interna e de passeio e permanência de pessoas nas restritas faixas de areia existentes. De comprometimento da qualidade da água do mar em sua balneabilidade, de aspectos microclimáticos como a insolação e ventilação adequadas, e por fim a perda irremediável e a degradação estética da qualidade cênica do morro e seu entorno que inicialmente se constituía num dos principais atrativos para a sua ocupação.

Em vista do exposto, recomendamos:

1- A sustação do modo de ocupação desencadeado pelos empreendimentos ora em construção e/ou aprovados, nos morros de Guarujá, exigindo dos responsáveis pelas construções existentes todas as obras de consolidação e infra-estrutura, sob pena de seqüestro das áreas (Lei Federal n. 6.766 de 19 de dezembro de 1979 Lei Lehmann).

2- Que o Ministério Público do Estado de São Paulo interfira junto à administração municipal no sentido de sustar alvarás aprovados pela Lei Municipal n. 1.555 de 26/06/81 e manter a legislação restritiva existente para os morros e maciços costeiros do Guarujá, incluindo as diretrizes relacionadas no item 3.

3- A elaboração de um plano paisagístico global para os morros e maciços costeiros do Guarujá, visando a sua conservação, e um projeto paisagístico parta a área do Morro do Sorocotuba visando a sua recuperação e conservação, que contenha: 
a) Ações para a consolidação de áreas degradadas, considerando-se a interação física das diversas áreas com a ação por bacias, por ser ineficaz empreender obras de drenagem, se não for detido o processo erosivo e montante;

b) Ações que norteiem os processos de expansão das ocupações, tais sejam:

b1) Proibição de construção nas bacias de captação de águas pluviais de cabeceiras em anfiteatros;

b2) Proibição de construção em vertentes íngremes, com declividade acima de $30 \%$, e propensas a escorregamentos e erosões;

b3) Proibição de construções em áreas próximas ou sobre costões e costeiras rochosas sujeitos aos respingos e embates das vagas;

b4) Instituição de normas para a execução de captação de águas pluviais, esgotos, abastecimento de água potável e a orientação de drenagem de forma a se adequar ao tipo de implantação desejado;

b5) Restrição a grandes intervenções na topografia original do terreno, expondo as camadas menos resistentes do solo ou executando cortes e aterros generalizados;

b6) Proteção com prática de reflorestamento nas áreas desprovidas de cobertura vegetal e sujeitas a erosão e desmoronamento;

b7) Execução do sistema viário, observando as curvas de nível, nunca vencendo perpendicularmente a linha de queda das encostas, adotando soluçōes técnicas que minimizam o surgimento de erosões;

b8) Adoção de padrões novos para as ruas que deverão ter menor largura, visando diminuir os volumes de terraplenagem e problemas para a implantação de habitaçōes;

b9) Permissão do acesso aos lotes por vias de pedestres e escadarias, eliminando a exigência de frente para a via pública, diminuindo o número de ruas;

b10) Adoção de esquemas que propiciem a implantação dos lotes no sentido das curvas de nível de maneira a diminuir o desnível da área ocupada pelas construções; 
b11) Definição de taxas de arborização para as áreas livres de edificações. privadas ou públicas, privilegiando a manutenção da vegetação existente. e o estabelecimento de critérios para sua localização e distribuição;

b12) Instituição de índices máximos de impermeabilização do solo;

b13) Estabelecimento de gabaritos para a altura máxima das edificações. bem como de seus recuos mínimos, de forma a conservar a linha do horizonte e manutenção de visuais importantes.

b14) Dimensionamento das densidades demográficas e definição dos usos compatíveis com a não depredação dos valores ambientais.

4- O desencadeamento de uma campanha de conscientização junto à população total (residente e temporária), da necessidade de conservação e valorização do patrimônio ambiental.

CEPA - Comissão de Estudos dos Problemas Ambientais da Universidade de São Paulo

Prof. Dr. Luiz Roberto Tommasi (coordenador - CEPA)

Prof. Silvio S. Macedo (FAU)

Prof. Paulo R. M. Pellegrino (FAU)

Profa. Marly Namur (FAU)

Prola. Dra. Olga Cruz (Dept. Geogr.)

Prof. Jurandyr L. S. Ross (Dept. Geogr.)

Profa. Dra. Sônia M. F. G. Galvão (IO)

Prof. Dr. Renato Herz (IO)

Terto originalmente publicado no Paisagem e Ambiente - Ensaios II.

Fotos: Prof. Dr. Renato Herz.

(*) Este relatório foi executado para atender solicitaçāo do Coordenador das Curadorias Especializadas de Proteşão ao Meio Ambiente. Ministério Público do Estado de Sāo Paulo. 